\title{
BRINE CONTAMINATION OF GROUND WATER AND STREAMS IN THE BAXTERVILLE OIL FIELD AREA, LAMAR AND MARION COUNTIES, MISSISSIPPI
}

By Stephen J. Kalkhoff

U.S. GEOLOGICAL SURVEY

Water-Resources Investigations Report 93-4147

Prepared in cooperation with the

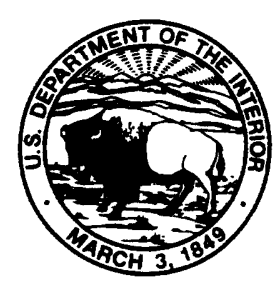

MISSISSIPPI DEPARTMENT OF ENVIRONMENTAL QUALITY, OFFICE OF POLLUTION CONTROL

Jackson, Mississippi

1993 


\section{U.S. DEPARTMENT OF THE INTERIOR \\ BRUCE BABBITT, Secretary}

U.S. GEOLOGICAL SURVEY

Robert M. Hirsch, Acting Director

For additional information write to:

District Chief

U.S. Geological Survey Suite 710, Federal Building 100 W. Capitol Street Jackson, Mississippi 39269
Copies of this report can be purchased from:

U.S. Geological Survey Earth Science Information Center Open-File Reports Section Box 25286, MS 517, Federal Center Denver, Colorado 80225 


\section{CONTENTS}

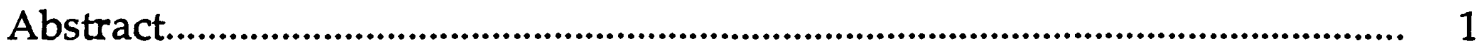

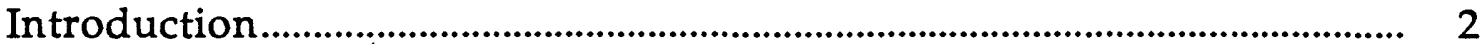

Background ..................................................................................................... 2

Purpose and scope ........................................................................................ 5

Acknowledgments ...................................................................................... 5

Location and topography ................................................................................ $\quad 5$

Geology ................................................................................................... 5

Hydrology ....................................................................................................... 9

Citronelle aquifer..................................................................................... 9

Miocene aquifer system................................................................... 12

Clear Creek and tributaries ........................................................ 12

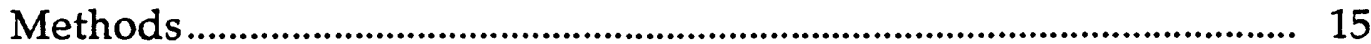

Ground-water contamination............................................................... 15

Citronelle aquifer.................................................................................... 16

Miocene aquifer system............................................................................ 17

Surface-water contamination................................................................ 19

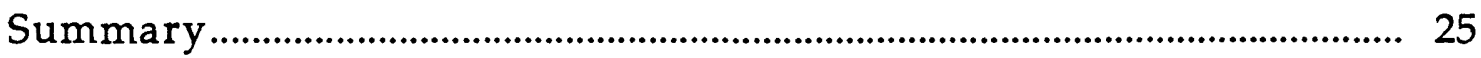

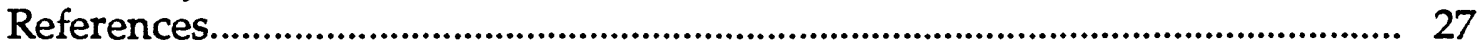

\section{ILLUSTRATIONS}

Figure 1. Map showing location of the study area, the Baxterville oil field, and trace of geologic sections..................................... 3

2. Graphs showing oil and brine production and the brine-to-oil production ratio in the Baxterville oil field... 4

3. Generalized geologic section A-A' in the Baxterville oil field..................................................................................... 7

4. Generalized geologic section B-B' in the Baxterville oil field...

5. Map showing location of wells for which hydraulic or waterquality data are used in this study...

6. Graphs showing monthly precipitation at Columbia, Mississippi, and water levels in the Citronelle aquifer and Miocene aquifer system in the study area.

7. Map showing location of surface-water sampling sites 


\section{ILLUSTRATIONS-Continued}

Figures 8-11. Graphs showing:

Page

8. Daily mean specific conductance and discharge at site 11 on Clear Creek

9. Frequency distribution of specific conductance at site 11 on Clear Creek

10. Specific conductance and stream discharge during selected periods in 1985 at site 11.

11. Relation between specific conductance and sodium and chloride concentrations at site 11 on Clear Creek, October 1984 to October 1985.

\section{TABLES}

Table 1. Records of selected wells for which hydraulic or waterquality data are used in this study.

2. Location and drainage area of selected surface-water sampling sites in the study area

3. Summary of analyses of brine samples from the Baxterville oil field.

4. Selected ground-water quality data for the study area.

5. Statistical summary of water-quality data for uncontaminated ground water in the Citronelle aquifer in the study area.

6. Statistical summary of water-quality data for uncontaminated ground water in the Miocene aquifer in the study area

7. Water-quality data for selected streams in the study area ....... 35

8. Water-quality data for Clear Creek and the Pearl River tributary during low-flow and high-flow periods. 


\section{CONVERSION FACTORS, VERTICAL DATUM, AND ABBREVIATIONS}

\begin{tabular}{|c|c|c|}
\hline Multiply & $\underline{B y}$ & To obtain \\
\hline inch (in.) & 25.4 & millimeter \\
\hline barrel & 0.1590 & cubic meter \\
\hline foot $(f t)$ & 0.3048 & meter \\
\hline foot per day $(\mathrm{ft} / \mathrm{d})$ & 0.3048 & meter per day \\
\hline mile (mi) & 1.609 & kilometer \\
\hline square mile $\left(\mathrm{mi}^{2}\right)$ & 2.590 & square kilometer \\
\hline cubic foot per second $\left(\mathrm{ft}^{3} / \mathrm{s}\right)$ & 0.02832 & cubic meter per second \\
\hline $\begin{array}{l}\text { cubic foot per day per square foot } \\
\text { times foot of aquifer thickness } \\
{\left[\left(\mathrm{ft}^{3} / \mathrm{d}\right) / \mathrm{ft}^{2}\right] \mathrm{ft}}\end{array}$ & 0.09290 & $\begin{array}{l}\text { cubic meter per day per } \\
\text { square meter times meter of } \\
\text { aquifer thickness }\end{array}$ \\
\hline gallon per day (gal/d) & 0.003785 & cubic meter per day \\
\hline $\begin{array}{l}\text { gallon per minute per foot } \\
{[(\mathrm{gal} / \mathrm{min}) / \mathrm{ft}]}\end{array}$ & 0.2070 & liter per second per meter \\
\hline
\end{tabular}

Sea level: In this report, "sea level" refers to the National Geodetic Vertical Datum of 1929--a geodetic datum derived from a general adjustment of the first-order level nets of the United States and Canada, formerly called Sea Level Datum of 1929.

Abbreviated water-quality units used in report:

$$
\begin{array}{ll}
\mathrm{mg} / \mathrm{L} & \text { milligram per liter } \\
\mu \mathrm{g} / \mathrm{L} & \text { microgram per liter } \\
\mu \mathrm{S} / \mathrm{cm} & \text { microsiemens per centimeter at } 25 \text { degrees Celsius }
\end{array}
$$




\title{
BRINE CONTAMINATION OF GROUND WATER AND STREAMS IN \\ THE BAXTERVILLE OIL FIELD AREA, LAMAR AND MARION \\ COUNTIES, MISSISSIPPI
}

By Stephen J. Kalkhoff

\begin{abstract}
A hydrologic investigation to define the extent of brine contamination in ground water and streams in the Baxterville oil field area was conducted from October 1984 through November 1985. The 260-square-mile study area includes the Baxterville oil field (approximately 12.5 square miles) in southwestern Lamar and southeastern Marion Counties, Mississippi. Since 1944, disposal of more than 1 billion barrels of brine pumped from the oilproducing zones has contaminated (increased chloride to greater than background concentrations) parts of the Citronelle and shallow Miocene aquifers and some streams that drain the oil field. Many domestic wells have been abandoned because of the presence of substantial quantities of brine in the ground water. Brine has moved laterally through the shallowest aquifers and discharged into Clear Creek and its tributaries. Although the presence of brine in surface water was greatest during periods of low flow when streamflow originated primarily from ground-water inflow, brine was also detected during high-flow periods when streamflow consisted largely of precipitation runoff.
\end{abstract}




\section{INTRODUCTION}

Large quantities of brine, water with a dissolved-solids concentration greater than $35,000 \mathrm{mg} / \mathrm{L}$, are produced in conjunction with petroleum. In Mississippi, where petroleum production began in 1939, disposal of brine has resulted in contamination of streams and aquifers. In the early years of oil production in the State, brine was pumped into nearby streams. In an attempt to avoid surface-water contamination, producers later pumped brine into evaporation ponds or pits. This practice led to the contamination of shallow ground water, and this disposal method was prohibited in 1978 (Mississippi State Oil and Gas Board, 1985, p. 91). Most of the brine produced in the Baxterville oil field is injected (1986) into the saline Cook Mountain Formation, which ranges in depth from 2,340 to $2,700 \mathrm{ft}$ below land surface (Bicker, 1972).

Information about the extent of brine contamination and about the movement and ultimate fate of the brine and the constituents that it contains is useful to local water planners and managers. To determine the extent of brine contamination, a study to collect water-quality data in oil-producing areas of Mississippi was begun in 1981 by the U.S. Geological Survey in cooperation with the Mississippi Department of Environmental Quality, Office of Pollution Control.

\section{Background}

The Baxterville oil field (fig. 1), located in southwestern Lamar and southeastern Marion Counties, is (1986) the most productive oil field in Mississippi. Oil production in the Baxterville oil field began on November 19, 1944. Production figures for the first few years of operation are not available, but more than 7.5 million barrels of oil were produced in 1948 (fig. 2). Production decreased and ranged from about 5 to 6 million barrels per year until 1970. Production increased in 1970 and reached a maximum of almost 8.9 million barrels in 1972. Since then, yearly oil production gradually decreased to approximately 4.4 million barrels in 1985 (Mississippi State Oil and Gas Board, 1984, 1985).

During initial development of oil reservoirs, relatively little brine in proportion to petroleum is brought to the surface. As petroleum is removed, however, formation water (brine) fills the pore spaces vacated by the oil, and subsequent pumping produces brine with the oil. The yearly brine production in Baxterville oil field gradually increased from about 1.7 million barrels in 1948 to about 20 million barrels in 1970. This increase continued through the 1970's and early 1980's, and brine production reached a 


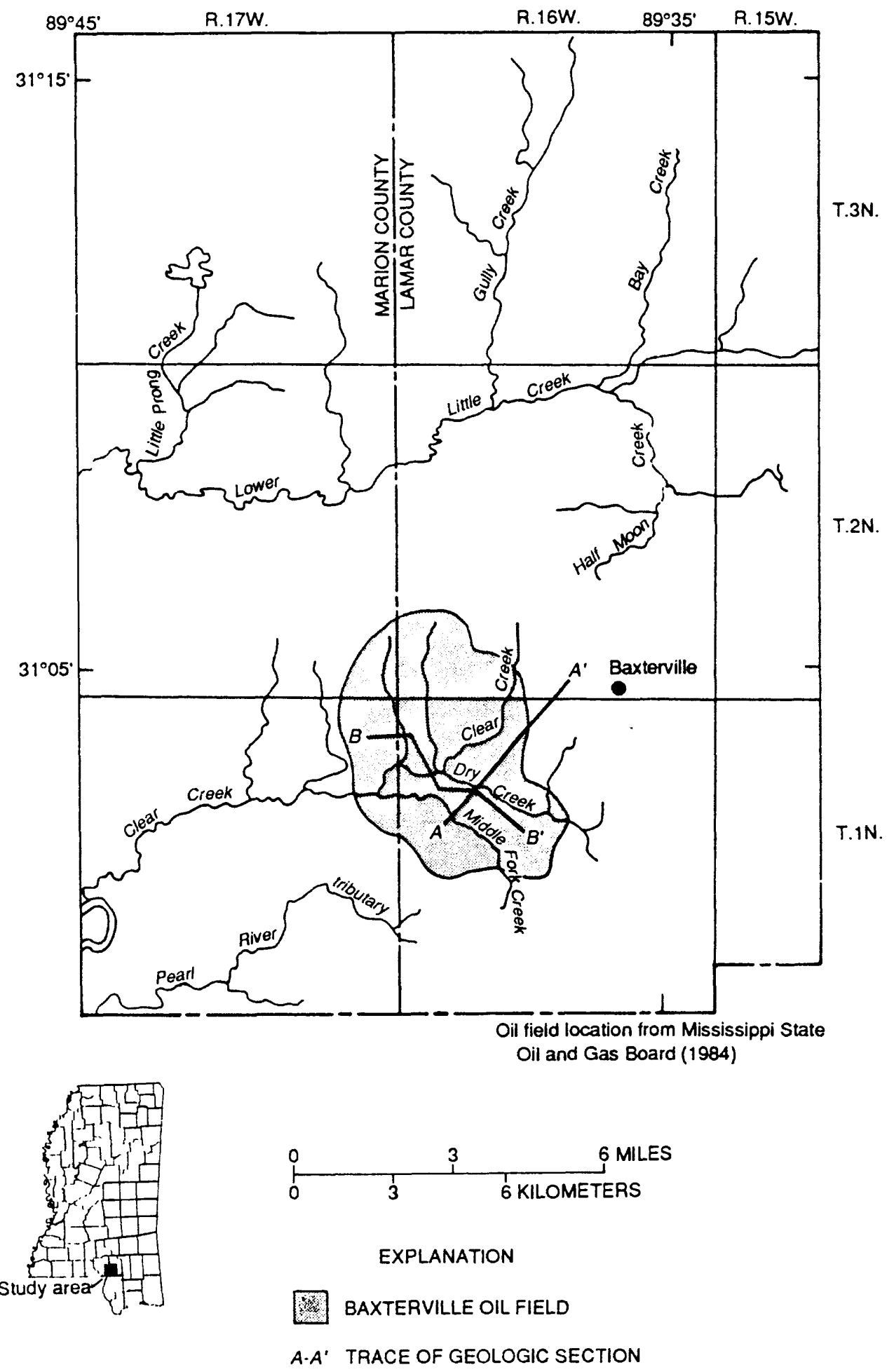

Figure 1.--Location of the study area, the Baxterville oil field, and trace of geologic sections. 

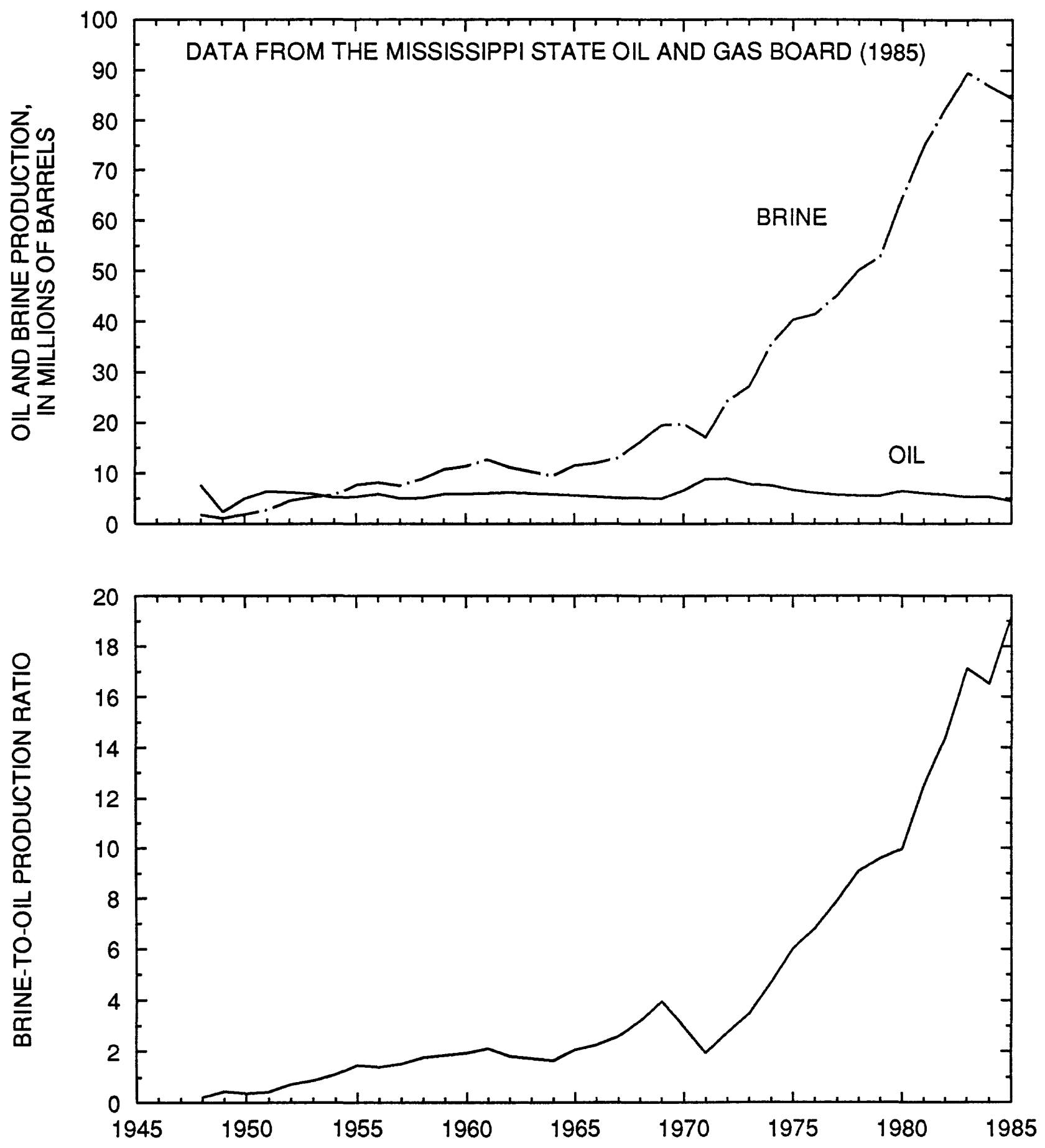

Figure 2.--Oil and brine production and the brine-to-oil production ratio in the Baxterville oil field. 
maximum of 89.5 million barrels in 1983 (fig. 2). More than 1 billion barrels of brine with chloride concentrations greater than $100,000 \mathrm{mg} / \mathrm{L}$ was produced from 1948 to 1985. A combination of decreasing oil production and increasing brine production caused a large increase in the brine-to-oil ratio in the 1970's and 1980's (Mississippi State Oil and Gas Board, 1984, 1985).

\section{Purpose and Scope}

This report defines the extent of oil-field-brine contamination in ground water and streams in the Baxterville oil field area. This report is based largely on data collected during the period October 1984 through November 1985. Water samples were collected from streams and wells in the study area. Data from a previous study conducted in the vicinity of the nearby Tatum Salt Dome were used for background water-quality information. Natural surfacewater quality was determined by sampling streamflow from a nearby basin having no oil field activities and from samples collected in an adjacent basin during a previous study.

\section{Acknowledgments}

Appreciation is extended to Mr. Fred Hille with the Mississippi Department of Environmental Quality, Office of Pollution Control, who arranged for the drilling and collection and analysis of water samples from five test wells in the study area, and to personnel with the Mississippi Department of Environmental Quality, Office of Geology, who ran electrical resistivity and gamma ray logs in the test wells.

\section{Location and Topography}

The 260- $\mathrm{mi}^{2}$ study area is located in southwestern Lamar and southeastern Marion Counties, Mississippi. The Baxterville oil field (approximately $12.5 \mathrm{mi}^{2}$ ) lies entirely within the study area. The study area is in the Pine Hills physiographic district, which is characterized as having a high and rolling land surface with moderately high ridges forming divides between streams (Cross and Wales, 1974, p. 7). Land in the study area is heavily forested, but a few flat areas have been cleared for agricultural purposes. In the oil field, much of the land is used for roads, well sites, storage tanks, pipelines, and other facilities related to oil production.

\section{Geology}

The geologic units that crop out or are present in the shallow subsurface in the study area are unconsolidated sedimentary deposits of Tertiary and 
Quaternary age. The deposits of Tertiary age include the undifferentiated Hattiesburg and Pascagoula Formations of the Miocene Series. The deposits of Quaternary age consist of the Citronelle Formation of the Pliocene Series.

Sediments of the undifferentiated Hattiesburg and Pascagoula Formations make up the upper part of the Miocene aquifer system described by Newcome (1975) and are the oldest and deepest units investigated in this study. Deposited in a nonmarine, near-shore environment (Bicker, 1969, p. 29), these units consist mainly of silty clays with minor amounts of sand. However, some prominent sand units exist in these sediments (Brown, 1944, p. 32). Stephenson and others (1928) assigned the exposed Miocene strata in the study area to the Pascagoula Formation; but in this report, the undifferentiated Hattiesburg and Pascagoula Formations are considered as one unit and are referred to as the Miocene Series. The undifferentiated strata consist of several distinct sand layers separated by clay and silt. Taylor (1971), in a report on the nearby Tatum Salt Dome, considered several of the sand layers to be separate aquifers. The two deepest sand layers (sand layer 1 and the local sand) may be equivalent to aquifer 1 and the local aquifer, respectively, in the Tatum Salt Dome area described by Taylor (1971).

Sand layer 1 and the local sand are the two principal sand units in the study area. Thicknesses of these sand units are shown in geologic sections in figures 3 and 4 . In section A-A' (fig. 3), sand layer 1 ranges in thickness from about $130 \mathrm{ft}$ in the northeastern part of the section near Baxterville to about $80 \mathrm{ft}$ in thickness near Middle Fork Creek, several miles to the southwest. The local sand layer ranges in thickness from less than $40 \mathrm{ft}$ in the northeastern part to about $120 \mathrm{ft}$ in the southwestern part of the section. Additional unnamed sand layers are present in the Miocene strata above the local sand layer in some areas. These sand layers appear to be discontinuous in the study area, and range from approximately 10 to more than $100 \mathrm{ft}$ in thickness (fig. 4).

Overlying the Miocene strata in the eastern part of the study area is the Citronelle Formation, which is composed of discontinuous sand and gravel units separated by sandy clay lenses. The Citronelle Formation is more than $200 \mathrm{ft}$ thick near the northeastern part of section A-A' (fig. 3) and thins to the southwest. The Citronelle Formation is absent from many stream valleys and areas of lower elevation (fig. 4). 


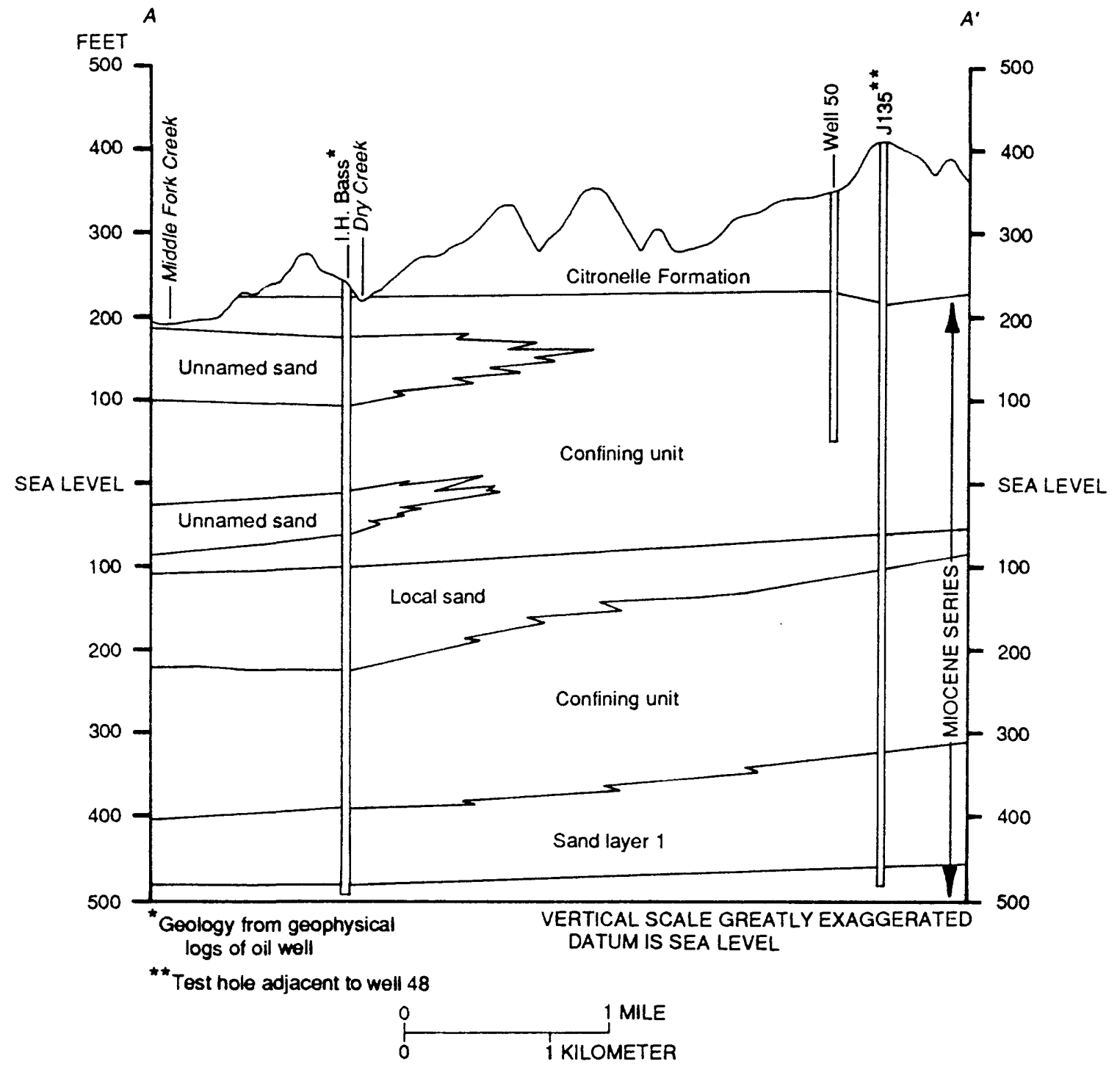

Figure 3.--Generalized geologic section $A-A^{\prime}$ in the Baxterville oil field. 


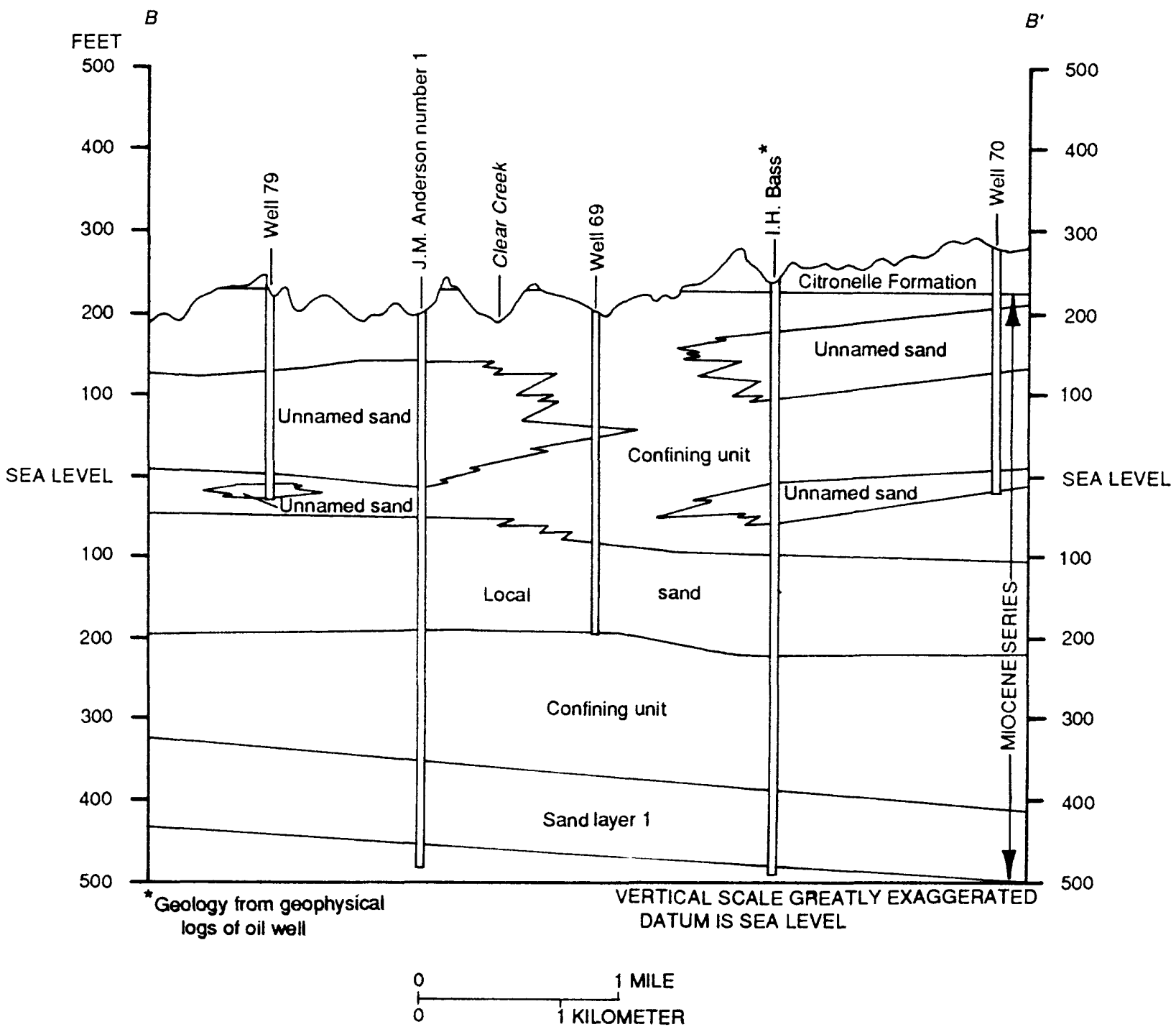

Figure 4.--Generalized geologic section $B-B^{\prime}$ in the Baxterville oil field. 


\section{Hydrology}

The geologic units of the Citronelle Formation and the Miocene Series that contain sufficient saturated permeable material to yield significant quantities of water serve as aquifers in the study area. These units are identified in this report as the Citronelle aquifer (Boswell, 1979) and the Miocene aquifer system (Newcome, 1975). The locations of wells for which hydraulic or water-quality data are used in this study are listed in table 1 and are shown in figure 5 .

\section{Citronelle Aquifer}

Water in the Citronelle aquifer originates from precipitation that percolates through the soil and unsaturated zones to the water table. From there, water moves downgradient and discharges into Clear Creek and its tributaries or downward into underlying hydraulically connected Miocene sands. The direction and rate of water movement are dependent on lithologic and hydrologic characteristics of the aquifer. Data on the hydraulic characteristics of the Citronelle aquifer are scarce, but the results of an aquifer test on a shallow well at Baxterville indicate that the aquifer has a transmissivity of about $13,000\left[\left(\mathrm{ft}^{3} / \mathrm{d}\right) / \mathrm{ft}^{2}\right] \mathrm{ft}$. [The term $\left[\left(\mathrm{ft}^{3} / \mathrm{d}\right) / \mathrm{ft}^{2}\right] \mathrm{ft}$ is hereafter reduced to $\mathrm{ft}^{2} / \mathrm{d}$, or feet squared per day.] The specific capacity of the aquifer at that site is $6.2(\mathrm{gal} / \mathrm{min}) / \mathrm{ft}$ and the hydraulic conductivity is $120 \mathrm{ft} / \mathrm{d}$ (Newcome, 1971, p. 30). Caution should be exercised in using these values, however, because the sands penetrated in this test may have included some sands not in the Citronelle Formation (Taylor and others, 1968, p. 66).

Water levels in the Citronelle aquifer change in response to precipitation and withdrawals. Water-level fluctuations in well 80 during the period 1961-65 are shown in figure 6. The water level in this well declined from March 1962 to March 1964 during a period of below normal rainfall, but began to recover in March 1964 in a delayed response to increased rainfall (Taylor, 1971 , p. 15). Water-level data were not collected during the 1984-85 study; however, on the basis of data previously collected in the area, water levels would be expected to rise during the wet spring months and to decline during the drier summer and fall months.

Few domestic wells are screened in the Citronelle aquifer in the study area, but two public-supply wells at Baxterville tap the Citronelle aquifer. Withdrawal of approximately $183,000 \mathrm{gal} / \mathrm{d}$ (J.A. Callahan, U.S. Geological Survey, oral commun., 1987) causes a cone of depression in the Citronelle water table at Baxterville. Ground-water movement in the Citronelle aquifer near Baxterville probably is toward this depression. In other parts of the study 

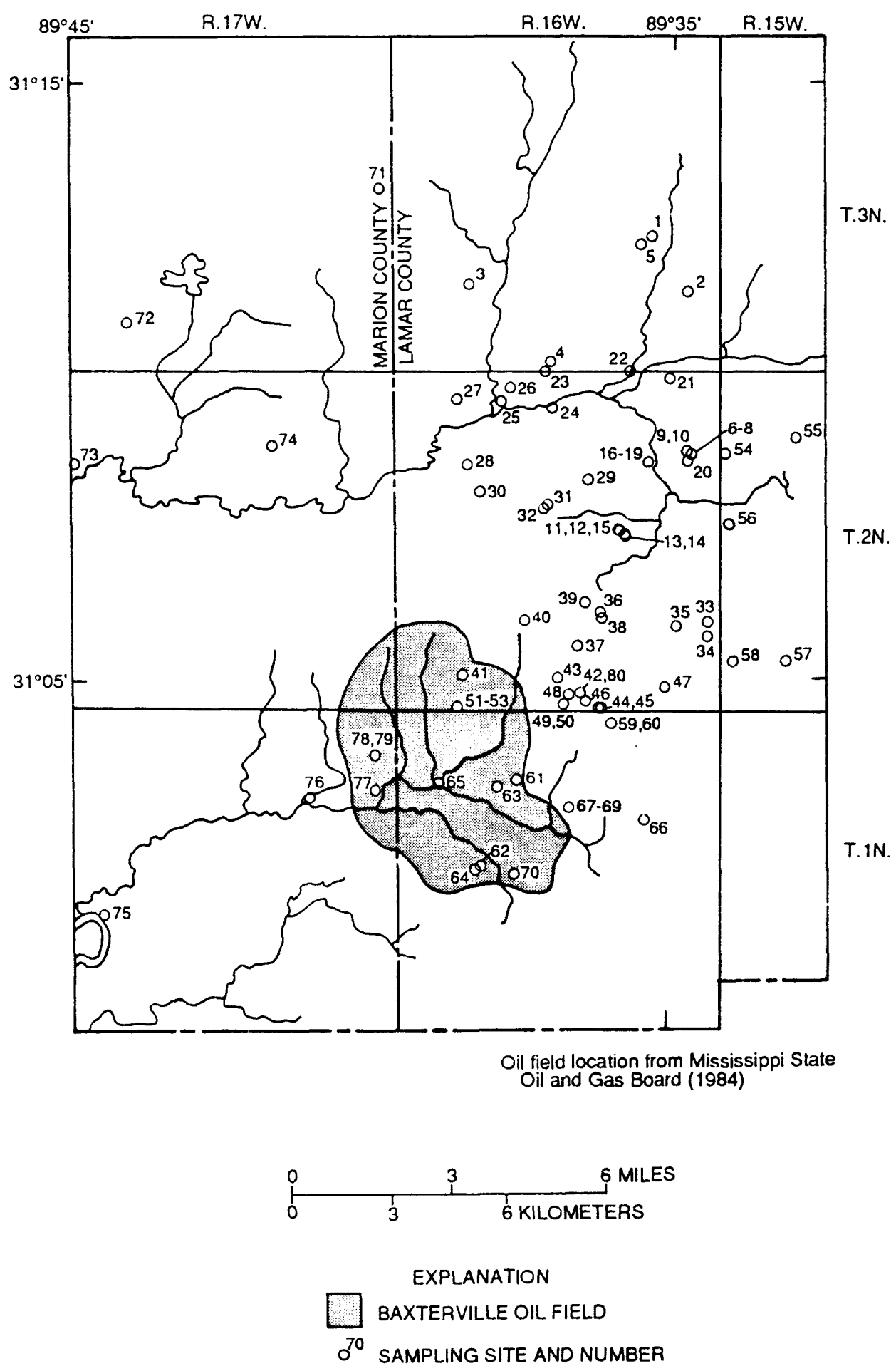

Figure 5.--Location of wells for which hydraulic or water-quality data are used in this study. 

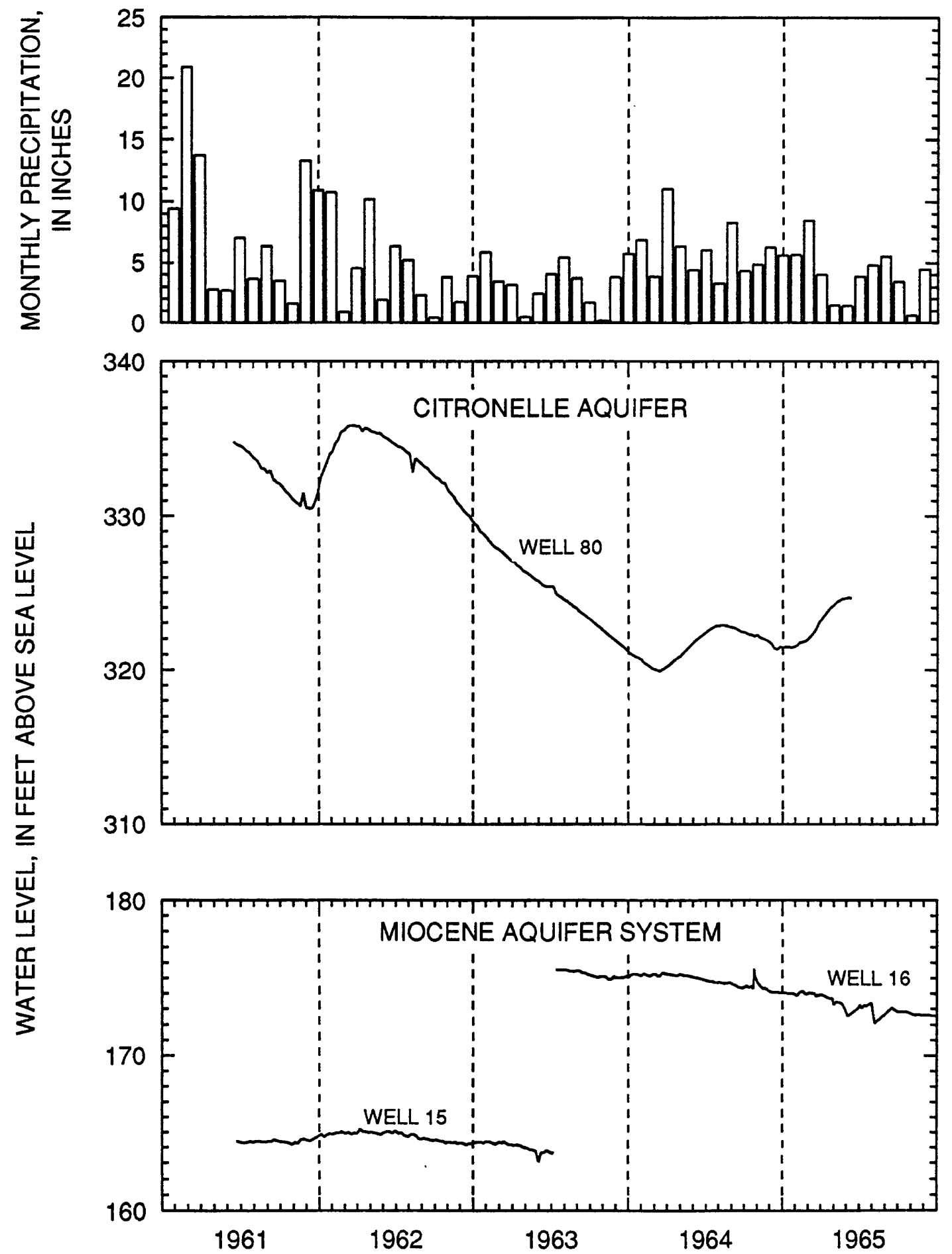

Figure 6.--Monthly precipitation at Columbia, Mississippi, and water levels in the Citronelle aquifer and Miocene aquifer system in the study area. 
area, ground-water movement is from topographic highs toward the streams and pumping wells. Generally, ground water moves from the ridges along the northern, eastern, and southern parts of the oil field toward Clear Creek.

\section{Miocene Aquifer System}

Water in the shallowest parts of the Miocene aquifer system in the study area originates as infiltration from the overlying Citronelle aquifer, as infiltration from terrace and alluvial deposits in the valleys, and as direct infiltration from rainfall where Miocene strata are exposed. Ground-water flow generally is down the dip to the south and southwest. Some water may be discharged into streams that incise the aquifer system.

The hydraulic conductivity and transmissivity of the Miocene aquifer system in the study area probably are similar to the average values of $95 \mathrm{ft} / \mathrm{d}$ and $13,000 \mathrm{ft}^{2} / \mathrm{d}$, respectively, reported by Newcome (1975) for the Miocene aquifer system in southern Mississippi.

Water levels in wells in the Miocene aquifer system rise and fall in response to general long-term trends in precipitation and changes in groundwater withdrawals, but seasonal and short-term variations in water levels generally are smaller in these aquifers than in the Citronelle aquifer (fig. 6).

\section{Clear Creek and Tributaries}

Baxterville oil field, in the southern one-half of the study area, is entirely within the Clear Creek drainage basin (fig. 1). Clear Creek originates north of the oil field and flows westward into the Pearl River. Dry and Middle Fork Creeks, the major tributaries to Clear Creek, drain the southern part of the oil field and two unnamed tributaries drain the northern part. .Most of the northern half of the study area is drained by Lower Little Creek and its tributaries. Locations of surface-water sites for which water-quality data are used in this report are listed in table 2 and are shown in figure 7.

During the study, daily mean discharges for Clear Creek downstream of the study area (site 11) ranged from about $11 \mathrm{ft}^{3} / \mathrm{s}$ on Sept. 20-22, 1985, to $835 \mathrm{ft}^{3} / \mathrm{s}$ on Oct. 30, 1985 (fig. 8). The largest daily mean discharge occurred as a result of rainfall associated with Hurricane Juan.

During the wettest months of the study period (November 1984 through March 1985) the discharge of Clear Creek characteristically peaked soon after a rain and then decreased rapidly (fig. 8). If a substantial quantity of rain did not fall within 4 or 5 days, the daily mean discharge of Clear Creek normally 


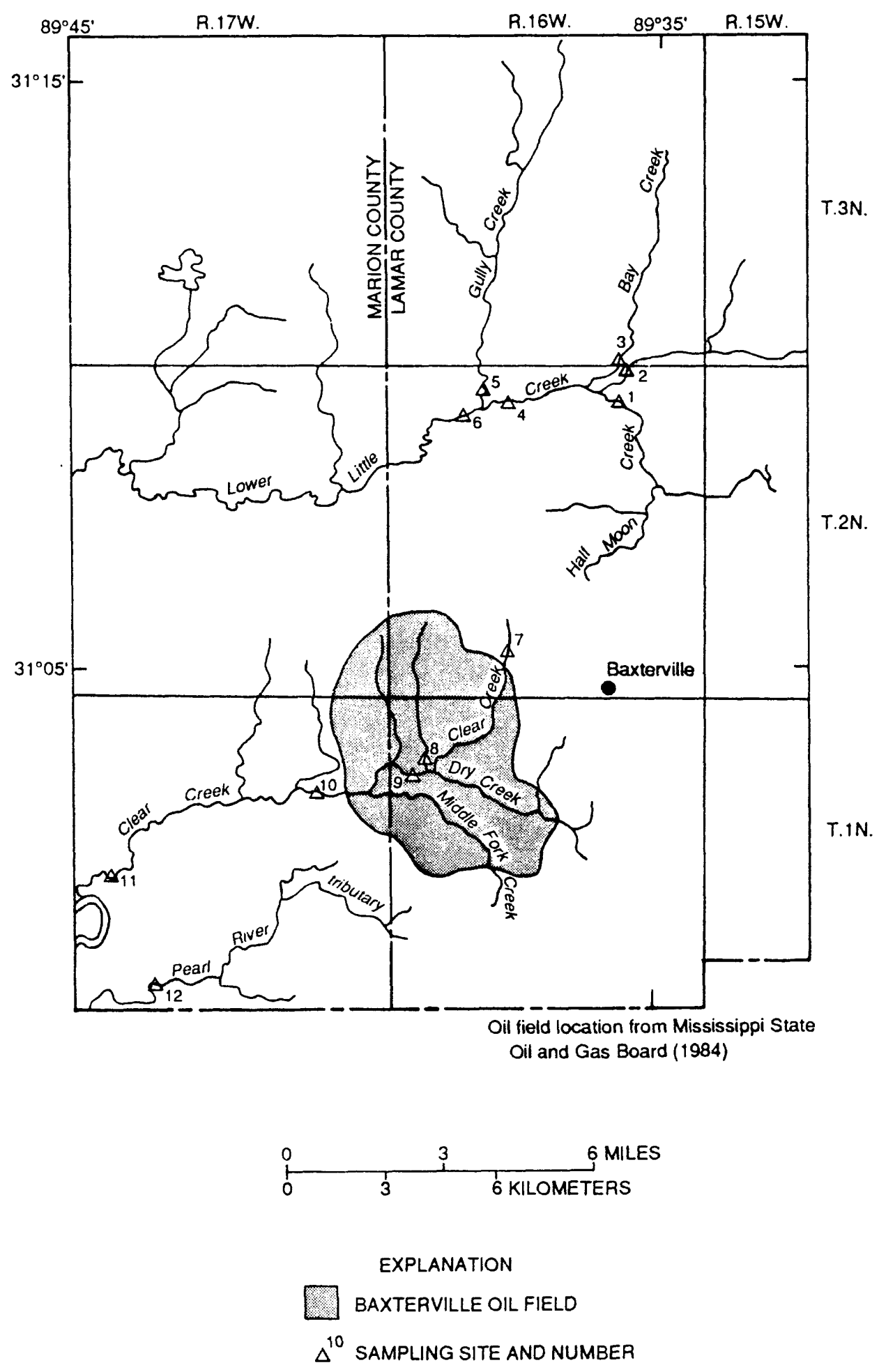

Figure 7.--Location of surface-water sampling sites. 

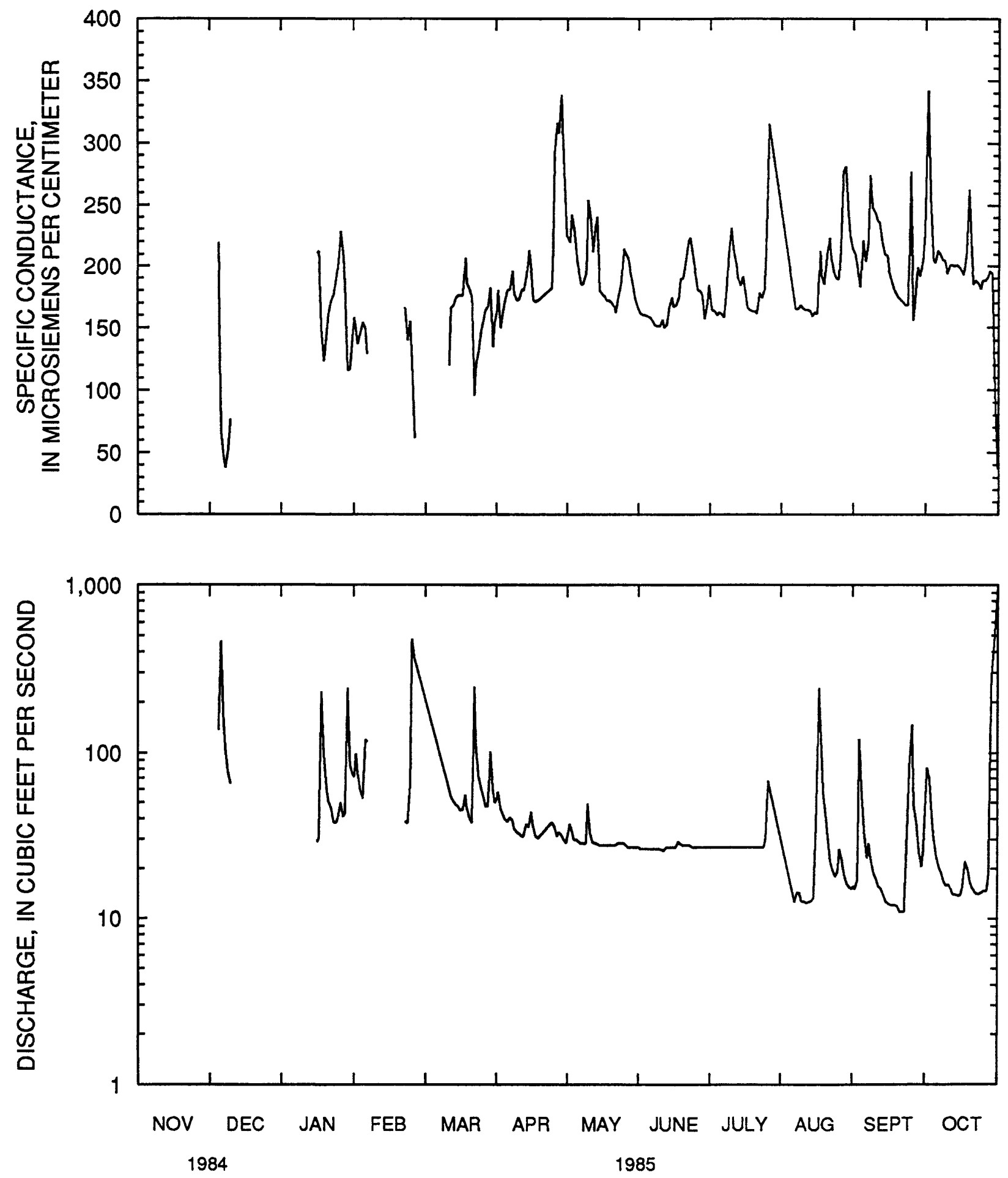

Figure 8.--Daily mean specific conductance and discharge at site 11 on Clear Creek.

14 
decreased to less than $40 \mathrm{ft}^{3} / \mathrm{s}$. During low-flow periods when streamflow originated primarily from ground-water discharge, streamflow at site 11 generally was less than $40 \mathrm{ft}^{3} / \mathrm{s}$.

Dry and Middle Fork Creeks (fig. 1) were dry during extended periods of no precipitation, whereas the unnamed tributaries flowed even during the driest period of August through mid October 1985. The difference in the base flows in these streams may reflect differences in the geologic makeup of the drainage basins.

\section{Methods}

Water samples were collected and analyzed to identify the presence of oilfield brine in ground water and streams in the Baxterville oil field area. The results were compared to water-quality data (collected during the study and from previous investigations) from nearby wells and streams outside the oil field area.

Ground-water samples were collected from 2 wells tapping the Citronelle aquifer, 12 wells tapping the Miocene aquifer system, and 5 test wells drilled during this study. Results of analyses of those samples were compared to water-quality data from 23 wells tapping the Citronelle aquifer and 26 wells tapping the Miocene aquifer system outside the oil field and unaffected by oilfield brines.

Surface-water samples were collected and analyzed from five sites in the Clear Creek Basin and from seven sites in nearby basins (fig. 7 and table 2). Six of the sites outside the oil-field area are in the Lower Little Creek Basin north of the oil field, and one site was on a Pearl River tributary south of the oil field. Surface-water-quality data generally were collected during periods of low flow, but at two sites (site 11 on Clear Creek and site 12 on a tributary to the Pearl River), samples were collected during both high- and low-flow periods. Water samples were analyzed to determine concentrations of major ions and of bromide, barium, and strontium, which are commonly present in relatively large concentrations in oil-field brines. At site 11 on Clear Creek, water temperature, specific conductance, and stage were monitored continuously throughout the study.

\section{GROUND-WATER CONTAMINATION}

Injection of brines into formations containing water with dissolved-solids concentrations greater than $10,000 \mathrm{mg} / \mathrm{L}$ is environmentally more acceptable than surface disposal, but this practice also can affect shallow ground-water 
quality. Improperly constructed and maintained or deteriorated injection wells may leak brine directly into shallow aquifers or allow brine to move upward through the annular space outside the well casing. Also, increased pressure in the injection zone may cause formation water to migrate up nearby abandoned production wells. If the casing of an abandoned well has deteriorated, the water may leak into freshwater aquifers.

Analyses of brines in earlier studies from two oil-producing formations (the Eutaw and the lower Tuscaloosa Formations of Cretaceous age) in the Baxterville oil field are summarized in table 3 . Sodium and chloride are the predominant constituents in water from both of these formations. Sodium concentrations exceed $50,000 \mathrm{mg} / \mathrm{L}$ and chloride concentrations are $100,000 \mathrm{mg} / \mathrm{L}$ or greater in brines from both of the oil-producing formations in the Baxterville oil field. The mean dissolved-solids concentration of brine from the shallower Eutaw Formation is about $170,000 \mathrm{mg} / \mathrm{L}$. The sodium to chloride ratio in this brine is about 0.54 . The Eutaw Formation brine contains relatively large concentrations of bromide (mean of $500 \mathrm{mg} / \mathrm{L}$ ) and barium plus strontium (mean of $63 \mathrm{mg} / \mathrm{L}$ ) that normally occur in very small concentrations in shallow ground water and streams. The brine from the deeper lower Tuscaloosa Formation is more mineralized than brine from the Eutaw Formation and has larger concentrations of calcium, magnesium, sulfate, and chloride. The sodium to chloride ratio in brine from the lower Tuscaloosa Formation is about 0.45 .

Water-quality data for wells that tap the Citronelle aquifer and the Miocene aquifer system in southwestern Lamar and southeastern Marion Counties are given in table 4. Comparisons of these data are discussed for each aquifer in the following sections.

\section{Citronelle Aquifer}

Uncontaminated water in the Citronelle aquifer in the study area is typically a calcium sodium bicarbonate water. Dissolved-solids concentrations (median concentration, $30 \mathrm{mg} / \mathrm{L}$ ) are small, and $\mathrm{pH}$ values (median 5.7) are low (table 5). Concentrations of major constituents generally are less than $10 \mathrm{mg} / \mathrm{L}$, but some sodium, chloride, and bicarbonate concentrations exceed that value. Consequently, a chloride concentration of $10 \mathrm{mg} / \mathrm{L}$ or less, is considered background level for water from the Citronelle aquifer for purposes of this study. Median concentrations of bromide (less than $0.01 \mathrm{mg} / \mathrm{L})$, barium $(48 \mu \mathrm{g} / \mathrm{L})$, and strontium $(12 \mu \mathrm{g} / \mathrm{L})$ are small. The median sodium to chloride ratio for the uncontaminated water is about 0.79 . 
Although the specific conductance of ground water in the Citronelle aquifer is relatively small, it varies seasonally in response to variations in rainfall. In water from well 46 , the specific conductance ranged from 18 to $36 \mu \mathrm{S} / \mathrm{cm}$ during a 3-year period (1963-66). Conductance values generally were largest during periods of little rainfall and smallest during or shortly after periods of large quantities of rainfall.

Few shallow wells were available for collecting water-quality samples in the Baxterville oil field because many domestic wells were abandoned or destroyed because of the presence of substantial quantities of brine in the ground water. In order to collect water-quality samples from the shallow Citronelle aquifer, a well (well 51, table 1) was drilled in the northern part of the oil field. The chloride concentration in water from this well was relatively small $(28 \mathrm{mg} / \mathrm{L})$, but was substantially larger than background concentrations. Chloride concentrations were less than $10 \mathrm{mg} / \mathrm{L}$ in water from other shallow Citronelle wells near and upgradient (northeast) of the oil field.

\section{Miocene Aquifer System}

Uncontaminated water in the Miocene aquifer system in the study area is typically a sodium bicarbonate water. The median dissolved-solids concentration is $160 \mathrm{mg} / \mathrm{L}$, the median $\mathrm{pH}$ is 6.8 (table 6). Concentrations of the major constituents, except for sodium and bicarbonate, generally are less than $20 \mathrm{mg} / \mathrm{L}$. Sodium to chloride ratios typically range (for the interquartile range or middle 50 percent of the data) from 1.5 to 5.9 .

The quality of uncontaminated water in the Miocene aquifer system has minor seasonal variations in response to variations in recharge, but the seasonal variations generally are much smaller than those in water in the Citronelle aquifer. The specific conductance of water from Miocene aquifer system well 41 , just northeast of the oil field, ranged from 225 to $235 \mu \mathrm{S} / \mathrm{cm}$ during the period 1963-66.

In the Baxterville oil field, areal variations in the quality of water in the Miocene aquifer system were large. A chloride concentration of $10 \mathrm{mg} / \mathrm{L}$ or less is considered background level for water from the Miocene aquifer system for purposes of this study. The maximum chloride concentration was $1,120 \mathrm{mg} / \mathrm{L}$ (table 4). Dissolved-solids concentrations ranged from less than 50 to $2,600 \mathrm{mg} / \mathrm{L}$ and strontium concentrations ranged from less than 20 to $2,000 \mu \mathrm{g} / \mathrm{L}$. 
Data collected from wells 78 and 79 (completed in the same test hole) indicate that a $20-\mathrm{ft}$ layer of freshwater overlies approximately $70 \mathrm{ft}$ of highly contaminated water in the shallow Miocene aquifer system at the site. The chloride concentration was $12 \mathrm{mg} / \mathrm{L}$ in water from well 78 screened at a depth from 126 to $147 \mathrm{ft}$ in the upper part of the aquifer system, whereas the chloride concentration was $1,120 \mathrm{mg} / \mathrm{L}$ in well 79 screened at a depth from 210 to $231 \mathrm{ft}$ near the base of the sand layer. Barium and strontium concentrations were less than 5 and $120 \mu \mathrm{g} / \mathrm{L}$, respectively, in water from the shallower well but were 4,100 and $2,000 \mu \mathrm{g} / \mathrm{L}$, respectively, in water from the deeper well.

Ground-water contamination was also detected at wells 67,68 , and 69 completed in another test hole. The chloride concentration was $163 \mathrm{mg} / \mathrm{L}$ in water from well 67 (depth $252 \mathrm{ft}$ ) screened in the shallowest sand layer; however, chloride concentrations were less than $5 \mathrm{mg} / \mathrm{L}$ in water from well 68 (depth $357 \mathrm{ft}$ ) screened in the middle of the underlying aquifer and well 69 (depth $410 \mathrm{ft}$ ) screened near the base of the local sand (fig. 4). Concentrations of barium and strontium each were less than $100 \mu \mathrm{g} / \mathrm{L}$ for the deeper wells (well 68 and well 69) but were 170 and $150 \mu \mathrm{g} / \mathrm{L}$, respectively, for shallow well 67.

Chloride concentrations for well 52 and well 53, completed in another test hole, were relatively small but did increase somewhat with depth. For well 52, which was screened at a depth of about $220 \mathrm{ft}$, the chloride concentration was $5.1 \mathrm{mg} / \mathrm{L}$. For well 53, screened at a depth of about $300 \mathrm{ft}$, the chloride concentration was $18 \mathrm{mg} / \mathrm{L}$, substantially larger than the background chloride concentration.

Chloride concentrations in water from some Miocene aquifer system wells in the Baxterville oil field not only were larger than the concentrations considered typical of uncontaminated ground water but also were increasing with time. Water-quality data for water from the Miocene aquifer system wells in the study area are scarce, but available data indicate that between 1982 and 1985, the specific conductance of water from well 65 increased from 100 to $160 \mu \mathrm{S} / \mathrm{cm}$, and chloride concentrations increased from 24 to $44 \mathrm{mg} / \mathrm{L}$. Although the chloride concentrations in most of the wells sampled during this study were less than the recommended limit of $250 \mathrm{mg} / \mathrm{L}$ for drinking water (U.S. Environmental Protection Agency, 1986), chloride concentrations and trends indicate that oil-field brines are present and are moving within the shallow Miocene aquifer system in the Baxterville oil field area. 


\section{SURFACE-WATER CONTAMINATION}

The extent of brine contamination in streams in the Baxterville oil field area was determined during this study by comparing the quality of water in Clear Creek, which drains the oil field, with that of streams outside the oil field. Water-quality data collected in the 1960's in the Lower Little Creek Basin north of the oil field indicate that streams unaffected by brines have a specific conductance of less than $50 \mu \mathrm{S} / \mathrm{cm}$ and a chloride concentration of less than $5 \mathrm{mg} / \mathrm{L}$ (sites 1 to 6, fig. 7 and table 7). During this study (1984-85), waterquality data were collected at two sites unaffected by oil-field brines -- on Clear Creek upstream of the oil field (site 7) and on a Pearl River tributary southwest of the oil field (site 12, fig. 7 and table 7). The quality of water at these sites (site 7 and site 12) was similar to that in Lower Little Creek in the 1960's (the specific conductance was less than $50 \mu \mathrm{S} / \mathrm{cm}$ and chloride concentration was less than $5 \mathrm{mg} / \mathrm{L}$ ).

Brine has moved laterally through the shallowest aquifers and discharged into Clear Creek and its tributaries. Although the presence of brine in surface water was greatest during periods of low flow when streamflow originated primarily from ground-water inflow, brine was also detected during highflow periods when streamflow consisted largely of precipitation runoff.

Water quality at site 12 on the Pearl River tributary (southwest of the oil field and unaffected by oil-field brines) varied with discharge (table 8 ). For the two samples, concentrations of dissolved solids and most major constituents were smaller during a high-flow period (March 1985) than during a low-flow period (October 1984). During high flow, the dissolved-solids concentration at site 12 was $29 \mathrm{mg} / \mathrm{L}$ (compared to $40 \mathrm{mg} / \mathrm{L}$ during low flow), and concentrations of most constituents were less than $5 \mathrm{mg} / \mathrm{L}$. Concentrations of sulfate and chloride were slightly larger in samples collected during high flow than during low flow but were less than $5 \mathrm{mg} / \mathrm{L}$.

The quality of water from site 11 on Clear Creek downstream of the oil field differs in many aspects from the quality of water from site 12 on the Pearl River tributary (table 8). Specific conductance and concentrations of dissolved solids and most constituents at site 11 were much smaller during high flow (March 1985) than during low flow (October 1984). During a lowflow period in October 1984, the dissolved-solids concentration at site 11 was $110 \mathrm{mg} / \mathrm{L}$, almost three times the dissolved-solids concentration at site 12 . The low-flow chloride concentration was $48 \mathrm{mg} / \mathrm{L}$ at site 11 but was only $3.8 \mathrm{mg} / \mathrm{L}$ at site 12 . The low-flow sodium to chloride ratio for water at site 11 was much smaller than for water at site 12 ( 0.44 and 0.74 , respectively, table 8) and was similar to the ratio for oil-field brine in the area ( 0.45 to 0.54 , table 3 ). 
During both high- and low-flow periods, concentrations of sodium, bromide, barium, and strontium, which are often associated with brines, were also substantially larger in Clear Creek than in the Pearl River tributary. Magnesium, potassium, bicarbonate, and sulfate concentrations were similar at both sites.

Although the concentrations of sodium, chloride, and other constituents at site 8 and site 9 on tributaries to Clear Creek (in the Baxterville oil field) and site 10 on Clear Creek (just downstream from the oil field) generally do not exceed the recommended limits for drinking water, they are substantially larger than concentrations in streams unaffected by oil-field brine and indicate the presence of brine in Clear Creek. Concentrations of sodium and chloride at these sites, similar to those at site 11 on Clear Creek, generally are largest during low-flow periods when streamflow consists largely of groundwater discharge. This relation indicates that shallow ground water in the drainage basin is affected by brine.

The specific conductance of water in Clear Creek was monitored at hourly intervals at site 11 throughout the study. Specific-conductance values at this site most frequently (about 75 percent of the samples) were from 160 to $240 \mu \mathrm{S} / \mathrm{cm}$ (fig. 9) and typically varied inversely with discharge (fig. 8). In several instances, however, the specific conductance increased abruptly, indicating likely contamination of Clear Creek by oil-field brines from surface runoff or by the release of brines directly into the stream. During Oct. 18-19, 1985 , the specific conductance increased from 230 to about $300 \mu \mathrm{S} / \mathrm{cm}$ and then decreased to about $175 \mu \mathrm{S} / \mathrm{cm}$ after a relatively small increase in discharge. On Oct. 28, 1985, the specific conductance increased from about 200 to about $300 \mu \mathrm{S} / \mathrm{cm}$ for a few hours before decreasing quickly as the stream discharge increased from about 30 to about $600 \mathrm{ft}^{3} / \mathrm{s}$ (fig. 10). On Sept. 30, 1985, the specific conductance increased abruptly from 200 to more than $1,000 \mu \mathrm{S} / \mathrm{cm}$ and remained higher than $1,000 \mu \mathrm{S} / \mathrm{cm}$ for most of the day (fig. 10). It is likely that the maximum specific conductance value on this day was substantially greater than $1,000 \mu \mathrm{S} / \mathrm{cm}$, but this value was the maximum that equipment at the site could measure. The conductance decreased to less than $500 \mu \mathrm{S} / \mathrm{cm}$ by October 1 and to less than $250 \mu \mathrm{S} / \mathrm{cm}$ by October 3 .

Sodium and chloride concentrations in Clear Creek were not determined during the period of apparent brine contamination on Sept. 30, 1985. However, the water-quality data collected at site 11 indicate the concentrations of these constituents were linearly related to specific conductance at 


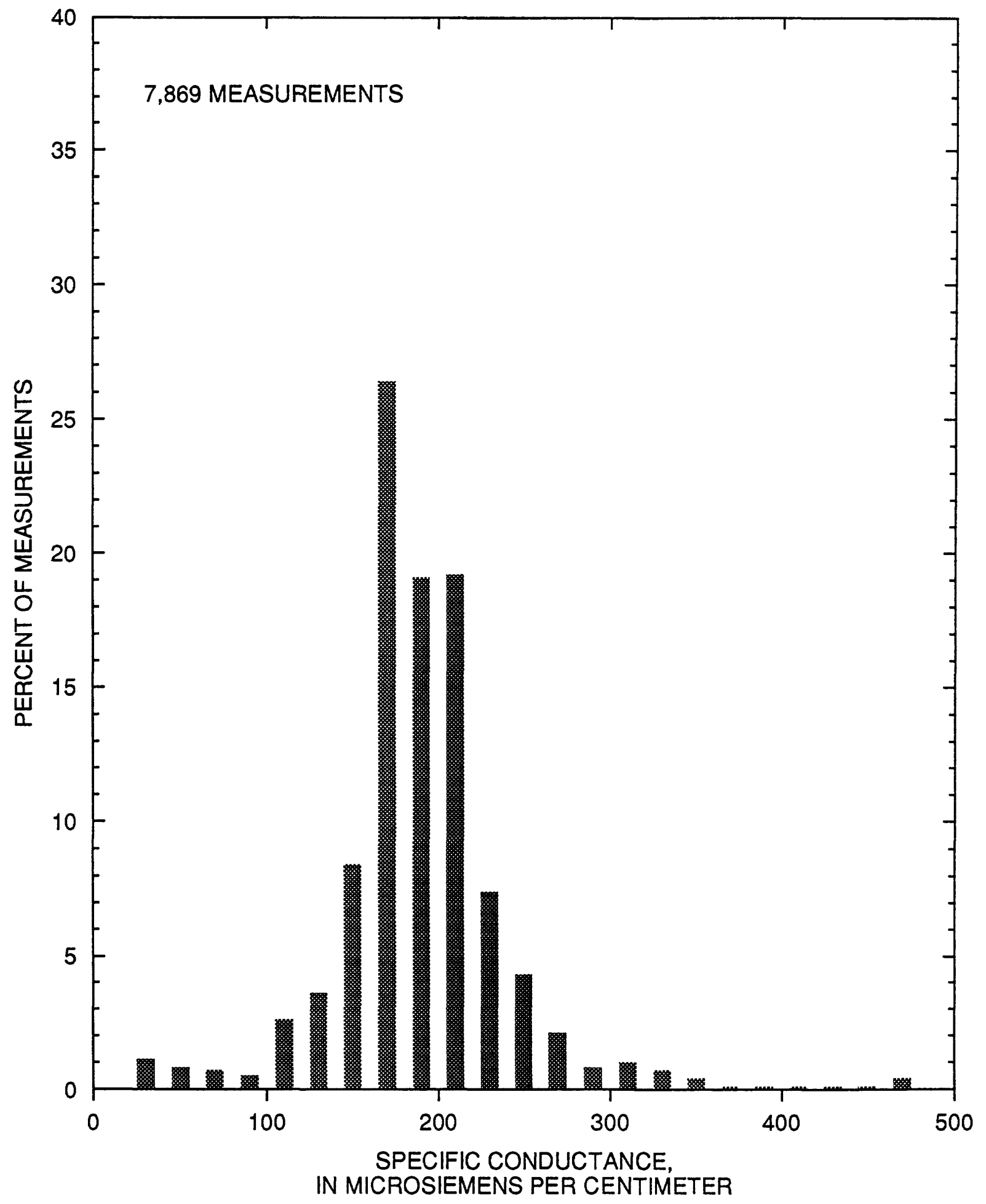

Figure 9.--Frequency distribution of specific conductance at site 11 on Clear Creek. 


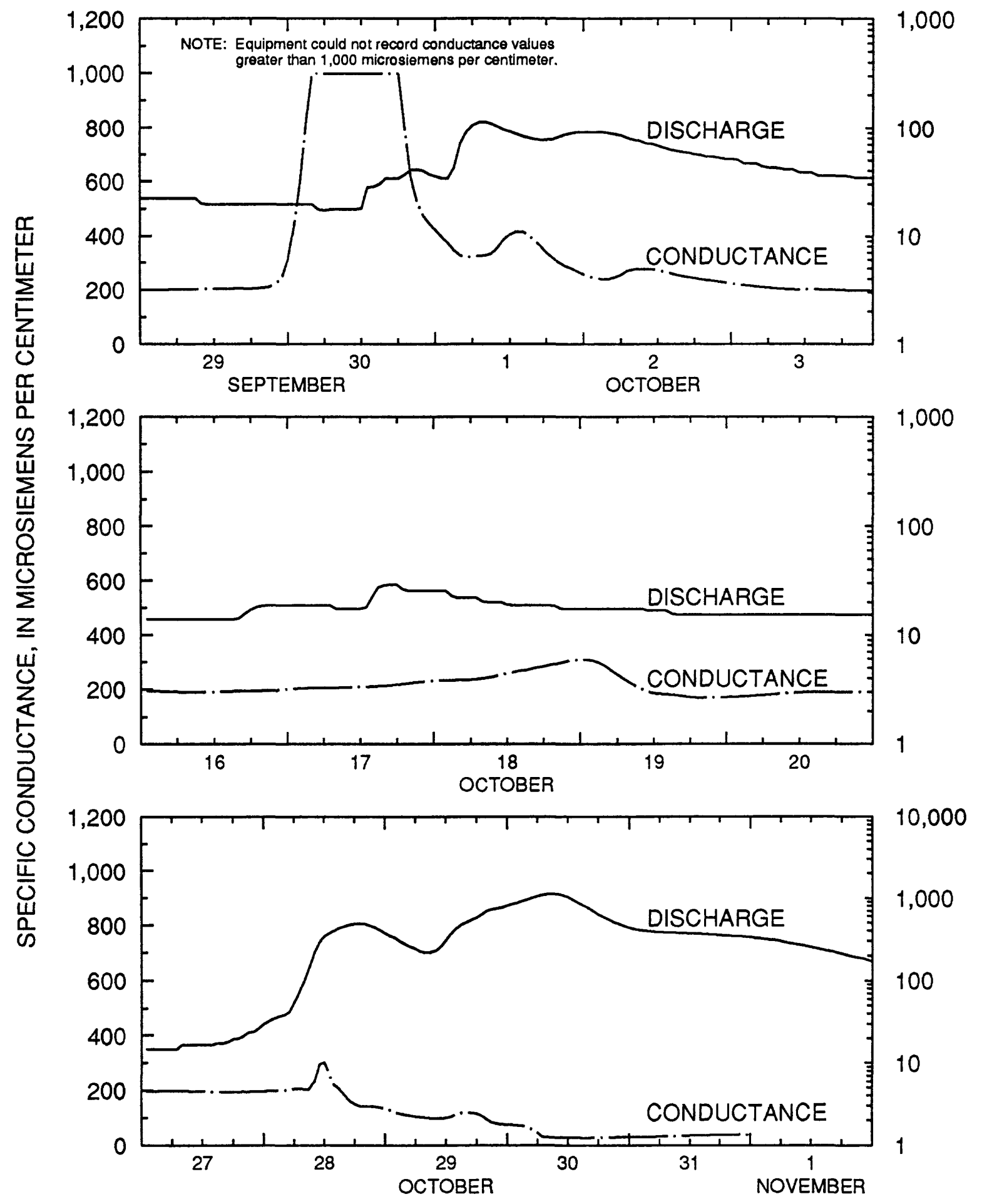

Figure 10.--Specific conductance and stream discharge during selected periods in 1985 at site 11. 
conductance values as large as $375 \mu \mathrm{S} / \mathrm{cm}$ (fig. 11). If these relations are valid at larger specific conductance values, the sodium concentrations exceeded $110 \mathrm{mg} / \mathrm{L}$ and the chloride concentrations exceeded $270 \mathrm{mg} / \mathrm{L}$ on Sept. 30, 1985. During the period of contamination, the chloride concentration probably exceeded the recommended limit for public water supplies.

When streamflow is low, as on Oct. 4, 1984, a major source of contamination in Clear Creek is from ground-water inflow. Water entering the oil field at site 7 had sodium and chloride concentrations of 1.6 and $3.4 \mathrm{mg} / \mathrm{L}$, respectively (table 7). Sodium and chloride concentrations had increased to 36 and $83 \mathrm{mg} / \mathrm{L}$, respectively, in water flowing from the oil field at site 10. The following equation can be used to calculate the mean chloride concentration of water entering Clear Creek between sampling sites.

where

$$
\left(C_{f}\right)\left(D_{f}\right)=\left(C_{S_{1}}\right)\left(D_{S_{1}}\right)+\ldots\left(C_{S_{n}}\right)\left(D_{S_{n}}\right),
$$

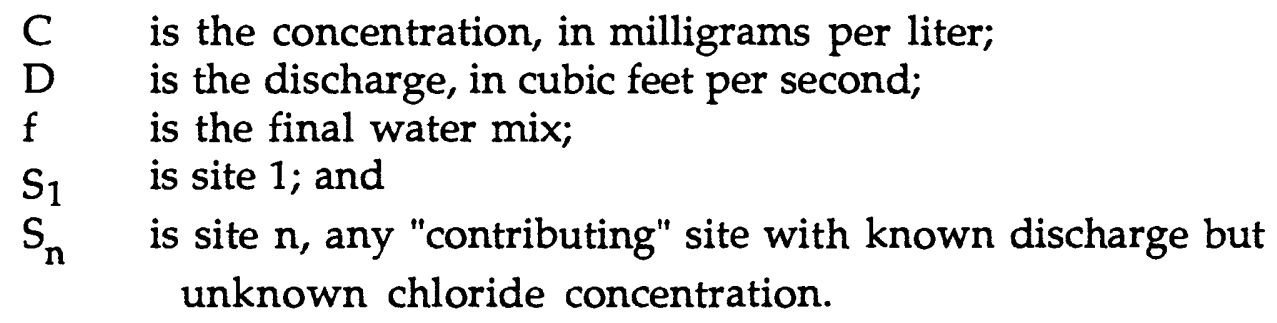

Discharge between sites 7 and 9 increased $6.16 \mathrm{ft} 3 / \mathrm{s}$. Approximately $0.54 \mathrm{ft}^{3} / \mathrm{s}$ of the increased streamflow originated from an unnamed tributary upstream of site 8. The remaining $5.62 \mathrm{ft} 3 / \mathrm{s}$ originated from Dry Creek and direct ground-water inflow. The mean chloride concentration is calculated using the equation above. Substituting the known concentration and discharge values for site 7 and site 8 , using the concentration and discharge from site 9 as the final water mix, and knowing that an additional $5.62 \mathrm{ft}^{3} / \mathrm{s}$ enters Clear Creek upstream of site 9, the only unknown left in the equation is the concentration of the additional water $\left(C_{a}\right)$ which is calculated from:

$$
(64)(7.63)=(3.4)(1.47)+(350)(0.54)+\left(C_{a}\right)(5.59) \text {. }
$$

The mean chloride concentration of the additional $5.62 \mathrm{ft}^{3} / \mathrm{s}$ groundwater inflow is $52 \mathrm{mg} / \mathrm{L}$. This calculated chloride concentration is substantially greater than the $3.4 \mathrm{mg} / \mathrm{L}$ at site 7 and $3.8 \mathrm{mg} / \mathrm{L}$ at site 12 and is evidence of additional sources of contamination other than from the unnamed tributaries sampled. 


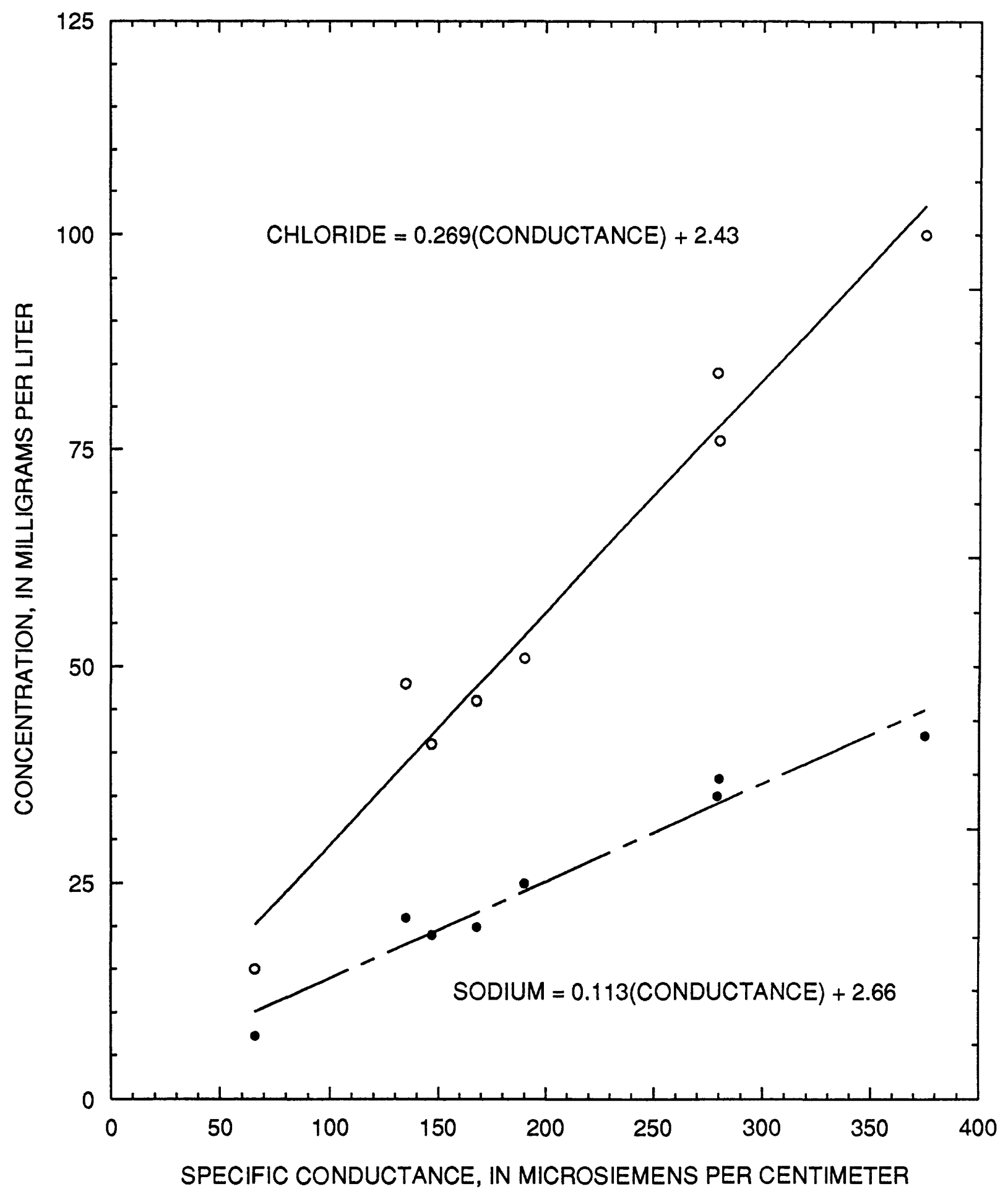

Figure 11.--Relation between specific conductance and sodium and chloride concentrations at site 11 on Clear Creek, October 1984 to October 1985. 
Also on Oct. 4, 1984, between sites 9 and 10, the discharge increased from 7.63 to $9.44 \mathrm{ft}^{3} / \mathrm{s}$ and chloride concentration increased from 64 to $83 \mathrm{mg} / \mathrm{L}$. The combined inflow from Middle Fork Creek, the smaller tributaries, and direct ground-water inflow, represented by this increase in discharge, had an estimated chloride concentration of $163 \mathrm{mg} / \mathrm{L}$.

The chloride concentration in surface water in the Baxterville oil field often exceeded $50 \mathrm{mg} / \mathrm{L}$ and was substantially larger than the concentration in nearby streams that do not drain the oil field. Streams in the oil-field area may also be subject to occasional contamination from surface runoff and other sources of brines that cause chloride concentrations to exceed the recommended limit of $250 \mathrm{mg} / \mathrm{L}$ for drinking water.

\section{SUMMARY}

A hydrologic investigation to define the extent of brine contamination in ground water and streams in the $260-\mathrm{mi}^{2}$ Baxterville oil field area was conducted from October 1984 through November 1985. The Baxterville oil field includes approximately $12.5 \mathrm{mi}^{2}$ in southwestern Lamar and southeastern Marion Counties, Mississippi. More than 1 billion barrels of brine with chloride concentrations greater than $100,000 \mathrm{mg} / \mathrm{L}$ have been produced in the Baxterville oil field since production began in 1944. Prior to the regulation of brine disposal (1978), brine was discharged to streams or pumped into evaporation ponds or pits where it could migrate into shallow freshwater aquifers.

Brine disposal in the Baxterville oil field has contaminated some ground water in the Citronelle aquifer. Few shallow wells were available for collecting water-quality samples in the oil field area because many domestic wells were abandoned and destroyed because of the presence of substantial quantities of brine in the ground water The chloride concentration in water from a well drilled during this study and completed in the shallow Citronelle aquifer in the northern part of the oil field was relatively small $(28 \mathrm{mg} / \mathrm{L})$, but was substantially larger than background concentrations (less than $10 \mathrm{mg} / \mathrm{L}$ ). Chloride concentrations were less than $10 \mathrm{mg} / \mathrm{L}$ in water from other shallow Citronelle wells near and upgradient (northeast) of the oil field.

In the Baxterville oil field, areal variations in the quality of water in the Miocene aquifer system were large--chloride concentrations ranged from less than $5 \mathrm{mg} / \mathrm{L}$ to $1,120 \mathrm{mg} / \mathrm{L}$. A chloride concentration of $10 \mathrm{mg} / \mathrm{L}$ or less is considered background level for water from the Miocene aquifer system. At one site a 20-ft layer of relatively fresh water (chloride concentration $12 \mathrm{mg} / \mathrm{L}$ ) overlies approximately $70 \mathrm{ft}$ of brine (chloride concentration $1,120 \mathrm{mg} / \mathrm{L}$ ) in 
the shallow Miocene aquifer system. At another site, moderately contaminated water (chloride concentration $163 \mathrm{mg} / \mathrm{L}$ ) in the shallowest sand layer overlies freshwater (chloride concentrations less than $5 \mathrm{mg} / \mathrm{L}$ ) in the middle of the underlying aquifer and near the base of the local sand. At a third site, chloride concentrations were relatively small but increased somewhat with depth $(5.1 \mathrm{mg} / \mathrm{L}$ at about $220 \mathrm{ft}$ to $18 \mathrm{mg} / \mathrm{L}$ at about $300 \mathrm{ft})$.

Although the chloride concentrations in most of the wells sampled during this study are less than the recommended limit of $250 \mathrm{mg} / \mathrm{L}$ for drinking water, chloride concentrations and trends indicate that oil-field brines are present and are moving within the shallow Miocene aquifer system in the Baxterville oil field area.

Brine has moved laterally through the shallowest aquifers and discharged into Clear Creek and its tributaries. Although the presence of brine in surface water was greatest during periods of low flow when streamflow originated primarily from ground-water inflow, brine was also detected during highflow periods when streamflow consisted largely of precipitation runoff.

During both high- and low-flow periods, concentrations of sodium, chloride, bromide, barium, and strontium, which are commonly associated with brines, were substantially larger in Clear Creek downstream of the oil field than in the Pearl River tributary (southwest of the oil field and unaffected by oil-field brines). However, concentrations of these constituents in Clear Creek and its tributaries generally do not exceed the recommended limits for drinking water. In a low-flow period during this study, the chloride concentration in water from Clear Creek ranged from less than $5 \mathrm{mg} / \mathrm{L}$ (background level for streams in the study area) upstream of the oil field to $83 \mathrm{mg} / \mathrm{L}$ downstream of the oil field. 


\section{REFERENCES}

Bicker, A.R., Jr.,1969, Copiah County geology and mineral resources: Mississippi Department of Natural Resources, Bureau of Geology, 172 p.

-----1972, Saltwater disposal wells in Mississippi: Mississippi Bureau of Geology Information Series MGS-72-4, $92 \mathrm{p}$.

Boswell, E.H., 1979, The Citronelle aquifers in Mississippi: U.S. Geological Survey Water-Resources Investigations Report 78-131, 1 sheet.

Brown, G.F., 1944, Geology and ground-water resources of the Camp Shelby area: Mississippi State Geological Survey Bulletin 58, 72 p.

Collins, G.A., Zelinski, W.P., and Pearson, C.A., 1966, Bromide and iodide in oil-field brines in some Tertiary and Cretaceous Formations in Mississippi and Alabama: U.S. Department of the Interior, Bureau of Mines Report of Investigations 6959, 27 p.

Cross, R.D., and Wales, R.W., 1974, Atlas of Mississippi: Jackson, Mississippi: University Press of Mississippi, $187 \mathrm{p}$.

Hawkins, M.E., Jones, O.W., and Pearson, C.A., 1963, Analysis of brines from oil-productive formations in Mississippi and Alabama: U.S. Department of the Interior, Bureau of Mines Report of Investigations 6167, $22 \mathrm{p}$.

Mississippi State Oil and Gas Board, 1984, Oil- and gas-field maps of Mississippi: $126 \mathrm{p}$.

----1985, Mississippi oil and gas production annual report: $315 \mathrm{p}$.

Newcome, Roy, Jr., 1971, Results of aquifer tests in Mississippi: Mississippi Board of Water Commissioners Bulletin 71-2, $44 \mathrm{p}$.

----1975, The Miocene aquifer system in Mississippi: U.S. Geological Survey Water-Resources Investigations Report 46-75, 3 sheets.

Stephenson, L.W., Logan, W.N., and Waring, G.N., 1928, The ground-water resources of Mississippi: U.S. Geological Survey Water-Supply Paper 576, $515 \mathrm{p}$. 
Taylor, R.E., 1971, Geohydrology of Tatum Salt Dome area, Lamar and Marion Counties, Mississippi: U.S. Atomic Energy Commission, National Technical Information Service, VUF-1023, 63 p.

Taylor, R.E., Humphreys, C.P., Jr., and Shattles, D.E., 1968, Water for industrial development in Covington, Jefferson Davis, Lamar, Lawrence, Marion, and Walthall Counties, Mississippi: Mississippi Research and Development Center, 114 p.

U.S. Environmental Protection Agency, 1986, Secondary maximum contaminant levels (section 143.3 of part 143, National secondary drinking-water regulations): U.S. Code of Federal Regulations, Title 40, Parts 100 to 149, revised as of July 1, 1986, p. 587-590. 
Table 1.--Records of selected wells for which hydraulic or water-quality data are used in this study

[CRNL, Citronelle Formation; MOCN, Miocene Series]

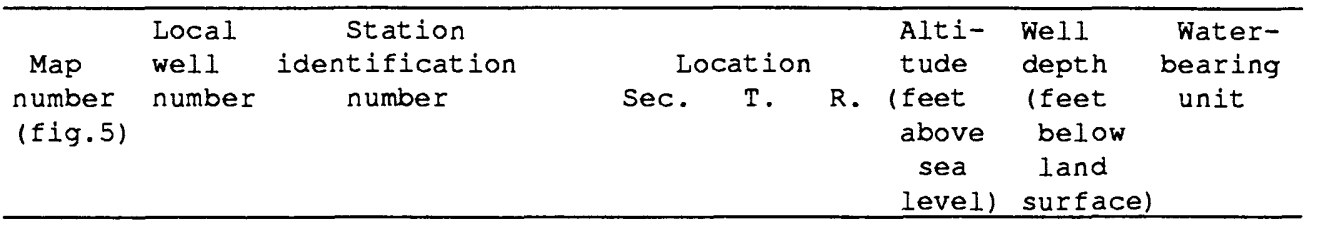

\begin{tabular}{|c|c|c|}
\hline 1 & F014 & 311220089340701 \\
\hline$?$ & F015 & 311125089334301 \\
\hline 3 & F019 & 311139089374101 \\
\hline 4 & F032 & 311024089361401 \\
\hline & FSO1 & 311214089341965 \\
\hline & J001 & 310856089333401 \\
\hline & $\mathrm{J} 002$ & 310856089333402 \\
\hline & J003 & 310856089333403 \\
\hline & J006 & 310858089333801 \\
\hline & J007 & 310859089334001 \\
\hline & J008 & 310749089345801 \\
\hline & J010 & 310749089345803 \\
\hline & J013 & 310746089345401 \\
\hline & JO14 & 310745089345201 \\
\hline & J015 & 310749089345601 \\
\hline & J017 & 310849089342202 \\
\hline & J018 & 310849089342203 \\
\hline & J019 & 310849089342204 \\
\hline & J020 & 310849089342205 \\
\hline & J041 & 310850089333901 \\
\hline & JO48 & 311002089340201 \\
\hline & J050 & 311014089343601 \\
\hline & J053 & 311015089362101 \\
\hline & $J 056$ & 310942089362401 \\
\hline & J059 & 310948089370701 \\
\hline & J060 & 311001089365801 \\
\hline & J066 & 310946089380301 \\
\hline & J074 & 310845089375301 \\
\hline & J079 & 310833089352601 \\
\hline & J082 & 310821089374001 \\
\hline & J083 & 310813089361401 \\
\hline & $J 084$ & 310809089361901 \\
\hline & $\mathrm{J} 104$ & 310625089331601 \\
\hline & $\mathrm{J} 105$ & 310611089331701 \\
\hline & $\mathrm{J} 106$ & 310620089335801 \\
\hline & $\mathrm{J} 109$ & 310633089352001 \\
\hline & $\mathrm{J} 110$ & 310602089354401 \\
\hline & $\mathrm{J} 111$ & 310628089351901 \\
\hline & $\mathrm{J} 113$ & 310643089353501 \\
\hline & $\mathrm{J} 114$ & 31062608936410 \\
\hline
\end{tabular}

Lamar county

\begin{tabular}{|c|c|c|c|c|c|}
\hline NWSW2 4 & $03 \mathrm{~N}$ & $16 \mathrm{~W}$ & 315 & 112 & CRNL \\
\hline SESW2 5 & $03 N$ & $16 \mathrm{~W}$ & 325 & 80 & CRNL \\
\hline SESW2 9 & $03 \mathrm{~N}$ & $16 \mathrm{~W}$ & 360 & 279 & MOCN \\
\hline SESE 33 & $03 N$ & $16 \mathrm{~W}$ & 200 & 230 & MOCN \\
\hline SESE 23 & $03 \mathrm{~N}$ & $16 \mathrm{~W}$ & 280 & -- & CRNL \\
\hline NWSE12 & $02 \mathrm{~N}$ & $16 \mathrm{~W}$ & 306 & 782 & MOCN \\
\hline NWSE 12 & $02 \mathrm{~N}$ & $16 \mathrm{~W}$ & 306 & 1,130 & MOCN \\
\hline NWSE 12 & $02 \mathrm{~N}$ & $16 \mathrm{~W}$ & 306 & 1,310 & MOCN \\
\hline NESW 12 & $02 \mathrm{~N}$ & $16 \mathrm{~W}$ & 283 & 1,096 & MOCN \\
\hline SENW12 & $02 \mathrm{~N}$ & $16 \mathrm{~W}$ & 272 & 887 & MOCN \\
\hline SWSW1 4 & $02 \mathrm{~N}$ & $16 \mathrm{~W}$ & 295 & 820 & MOCN \\
\hline SWSW 14 & $02 \mathrm{~N}$ & $16 \mathrm{~W}$ & 295 & 1,400 & MOCN \\
\hline SWSW14 & $02 \mathrm{~N}$ & $16 \mathrm{~W}$ & 292 & 986 & MOCN \\
\hline SESW14 & $02 \mathrm{~N}$ & $16 \mathrm{~W}$ & 290 & 986 & MOCN \\
\hline SWSW14 & $02 \mathrm{~N}$ & $16 \mathrm{~W}$ & 294 & 366 & MOCN \\
\hline NENE14 & $02 \mathrm{~N}$ & $16 \mathrm{~W}$ & 266 & 474 & MOCN \\
\hline SENE14 & $02 \mathrm{~N}$ & $16 \mathrm{~W}$ & 264 & 667 & MOCN \\
\hline NENE14 & $02 \mathrm{~N}$ & $16 \mathrm{~W}$ & 266 & 762 & MOCN \\
\hline SENEI 4 & $02 \mathrm{~N}$ & $16 \mathrm{~W}$ & 265 & 860 & MOCN \\
\hline NWSE12 & $02 \mathrm{~N}$ & $16 W$ & 330 & 62 & CRNL \\
\hline SENWO1 & $02 \mathrm{~N}$ & $16 \mathrm{~W}$ & 285 & 29 & CRNL \\
\hline SWSE 35 & $03 \mathrm{~N}$ & $16 \mathrm{~W}$ & 250 & 367 & MOCN \\
\hline SWSE33 & $03 \mathrm{~N}$ & $16 \mathrm{~W}$ & 250 & 212 & MOCN \\
\hline NESEO 4 & $02 \mathrm{~N}$ & $16 \mathrm{~W}$ & 210 & 21 & CRNL \\
\hline NWSWO 4 & $02 \mathrm{~N}$ & $16 \mathrm{~W}$ & 230 & 196 & MOCN \\
\hline SWNWO 4 & $02 \mathrm{~N}$ & $16 W$ & 235 & 19 & CRNL \\
\hline NESWO 5 & $02 \mathrm{~N}$ & $16 \mathrm{~W}$ & 220 & 225 & MOCN \\
\hline SESWO 8 & $02 \mathrm{~N}$ & $16 \mathrm{~W}$ & 250 & 280 & MOCN \\
\hline NENE10 & $02 \mathrm{~N}$ & $16 \mathrm{~W}$ & 325 & 43 & CRNL \\
\hline SESWI 6 & $02 \mathrm{~N}$ & $16 \mathrm{~W}$ & 390 & 60 & CRNL \\
\hline SENEI 6 & $02 \mathrm{~N}$ & $16 \mathrm{~W}$ & 365 & 70 & CRNL \\
\hline SENE1 6 & $02 \mathrm{~N}$ & $16 \mathrm{~W}$ & 360 & 66 & CRNL \\
\hline NESE 25 & $02 \mathrm{~N}$ & $16 W$ & 340 & 61 & CRNL \\
\hline SENE 25 & $02 \mathrm{~N}$ & $16 \mathrm{~W}$ & 365 & 71 & CRNL \\
\hline SWNE2 5 & $02 \mathrm{~N}$ & $16 \mathrm{~W}$ & 340 & 60 & CRNL \\
\hline NENE2 7 & $02 \mathrm{~N}$ & $16 \mathrm{~W}$ & 325 & 38 & CRNL \\
\hline SESW2 7 & $02 \mathrm{~N}$ & $16 \mathrm{~W}$ & 390 & 95 & CRNL \\
\hline SENE2 7 & $02 \mathrm{~N}$ & $16 \mathrm{~W}$ & 335 & 36 & CRNL \\
\hline NWNE2 7 & $02 \mathrm{~N}$ & $16 W$ & 335 & 65 & CRNL \\
\hline SWSE2 8 & $02 \mathrm{~N}$ & $16 \mathrm{~W}$ & 400 & 110 & CRN \\
\hline
\end{tabular}


Table 1.--Records of selected wells for which hydraulic or water-quality data are used in this study--Continued

\begin{tabular}{|c|c|c|c|c|c|c|c|c|}
\hline $\begin{array}{l}\text { Map } \\
\text { number } \\
\text { (fig.5) }\end{array}$ & $\begin{array}{l}\text { Local } \\
\text { well } \\
\text { number }\end{array}$ & $\begin{array}{cc}\text { Station } \\
\text { identification } \\
\text { number }\end{array}$ & $\begin{array}{l}\text { Lo } \\
\text { Sec. }\end{array}$ & $\begin{array}{c}\text { catio } \\
\text { T. }\end{array}$ & R. & $\begin{array}{l}\text { Alti- } \\
\text { tude } \\
\text { (feet } \\
\text { above } \\
\text { sea } \\
\text { level) }\end{array}$ & $\begin{array}{l}\text { Well } \\
\text { depth } \\
\text { (feet } \\
\text { below } \\
\text { land } \\
\text { surface) }\end{array}$ & $\begin{array}{l}\text { Water- } \\
\text { bearing } \\
\text { unit }\end{array}$ \\
\hline 41 & $\mathrm{~J} 117$ & 310542089375301 & NENW32 & $02 \mathrm{~N}$ & $16 \mathrm{~W}$ & 373 & 454 & MOCN \\
\hline 42 & J120 & 310519089354201 & NWSE34 & $02 \mathrm{~N}$ & $16 \mathrm{~W}$ & 400 & 132 & CRNL \\
\hline 43 & $\mathrm{~J} 122$ & 310533089360601 & SWNW34 & $02 \mathrm{~N}$ & $16 \mathrm{~W}$ & 390 & 138 & CRNL \\
\hline 44 & $\mathrm{~J} 123$ & 310504089352101 & SESE34 & $02 \mathrm{~N}$ & $16 \mathrm{~W}$ & 400 & 175 & CRNL \\
\hline 45 & $\mathrm{~J} 124$ & 310505089352301 & SWSE24 & $02 \mathrm{~N}$ & $16 \mathrm{~W}$ & 412 & 125 & CRNL \\
\hline 46 & J125 & 310510089353601 & SWSE34 & $02 \mathrm{~N}$ & $16 \mathrm{~W}$ & 395 & 100 & CRNL \\
\hline 47 & J133 & 310525089335901 & SWNE25 & $02 \mathrm{~N}$ & $16 \mathrm{~W}$ & 340 & 61 & CRNL \\
\hline 48 & $\mathrm{~J} 136$ & 310517089355501 & SWNE34 & $02 \mathrm{~N}$ & $16 \mathrm{~W}$ & 416 & 200 & CRNL \\
\hline 49 & J287 & 310508089360001 & SWSW34 & $02 \mathrm{~N}$ & $16 \mathrm{~W}$ & 354 & 147 & CRNL \\
\hline 50 & $\mathrm{~J} 288$ & 310508089360002 & SWSW34 & $02 \mathrm{~N}$ & $16 \mathrm{~W}$ & 354 & 231 & $\mathrm{MOCN}$ \\
\hline 51 & J289 & 310512089380001 & SWSW32 & $02 \mathrm{~N}$ & $16 \mathrm{~W}$ & 330 & 74 & CRNL \\
\hline 52 & J290 & 310512089380002 & SWSW32 & $02 \mathrm{~N}$ & $16 \mathrm{~W}$ & 330 & 231 & MOCN \\
\hline 53 & J291 & 310512089380003 & SWSW32 & $02 \mathrm{~N}$ & $16 \mathrm{~W}$ & 330 & 315 & MOCN \\
\hline 54 & $\mathrm{~K} 004$ & 310857089330001 & SWNW07 & $02 \mathrm{~N}$ & $15 \mathrm{~W}$ & 360 & 90 & CRNL \\
\hline 55 & $\mathrm{~K} 007$ & 310917089314301 & NENWO 8 & $02 \mathrm{~N}$ & $15 \mathrm{~W}$ & 360 & 130 & CRNL \\
\hline 56 & $\mathrm{~K} 013$ & 310758089325601 & NWSW1 8 & $02 \mathrm{~N}$ & $15 \mathrm{~W}$ & 330 & 62 & CRNL \\
\hline 57 & $\mathrm{~K} 032$ & 310546089320201 & SWNE32 & $02 \mathrm{~N}$ & $15 \mathrm{~W}$ & 365 & 85 & CRNL \\
\hline 58 & $\mathrm{KO} 42$ & 310547089325901 & NWNW31 & $02 \mathrm{~N}$ & $15 \mathrm{~W}$ & 380 & 70 & CRNL \\
\hline 59 & M006 & 310450089351001 & SWNW02 & $01 \mathrm{~N}$ & $16 \mathrm{~W}$ & 410 & 170 & CRNL \\
\hline 60 & M007 & 310450089351002 & SENWO2 & $01 \mathrm{~N}$ & $16 \mathrm{~W}$ & 412 & 173 & CRNL \\
\hline 61 & MO12 & 310352089365401 & NWSEO9 & $01 \mathrm{~N}$ & $16 \mathrm{~W}$ & 300 & 510 & MOCN \\
\hline 62 & M021 & 310227089374201 & SESW 17 & $01 \mathrm{~N}$ & $16 \mathrm{~W}$ & 270 & 185 & CRNL \\
\hline 63 & M022 & 310346089371501 & SENE08 & $01 \mathrm{~N}$ & $16 \mathrm{~W}$ & 275 & 425 & MOCN \\
\hline 64 & M085 & 310224089374701 & SESW 17 & $01 \mathrm{~N}$ & $16 \mathrm{~W}$ & 270 & -- & MOCN \\
\hline 65 & M086 & 310402089382201 & NESEO 7 & $01 \mathrm{~N}$ & $16 \mathrm{~W}$ & 240 & 235 & MOCN \\
\hline 66 & M098 & 310320089343601 & SWSEI1 & $01 \mathrm{~N}$ & $16 \mathrm{~W}$ & 367 & 100 & CRNL \\
\hline 67 & $\mathrm{M} 101$ & 310331089382801 & NWSEO7 & $01 \mathrm{~N}$ & $16 \mathrm{~W}$ & 210 & 252 & MOCN \\
\hline 68 & $\mathrm{M} 102$ & 310331089382802 & NWSEO 7 & $01 \mathrm{~N}$ & $16 \mathrm{~W}$ & 210 & 357 & MOCN \\
\hline 69 & M103 & 310331089382803 & NWSE07 & $01 \mathrm{~N}$ & $16 \mathrm{~W}$ & 210 & 410 & MOCN \\
\hline \multirow[t]{2}{*}{70} & $\mathrm{M} 104$ & 310256089364601 & SENWI 6 & $01 \mathrm{~N}$ & $16 \mathrm{~W}$ & 283 & 143 & MOCN \\
\hline & \multicolumn{8}{|c|}{ Marion County } \\
\hline 71 & M0O4 & 311310089392901 & NESE 13 & $03 \mathrm{~N}$ & $17 W$ & 390 & 327 & $\mathrm{MOCN}$ \\
\hline 72 & M055 & 311105089440001 & NWNE 32 & $03 \mathrm{~N}$ & $17 W$ & 220 & 250 & MOCN \\
\hline 73 & P023 & 310852089450001 & NESWO 7 & $02 \mathrm{~N}$ & $17 \mathrm{~W}$ & 150 & 1,028 & MOCN \\
\hline 74 & P060 & 310906089412401 & SENE1O & $02 \mathrm{~N}$ & $17 \mathrm{~W}$ & 247 & 281 & MOCN \\
\hline 75 & $\mathrm{R} 002$ & 310141089443501 & SWSE19 & $01 \mathrm{~N}$ & $17 \mathrm{~W}$ & 100 & 850 & MOCN \\
\hline 76 & $\mathrm{R} 028$ & 310342089405401 & NESW11 & $01 \mathrm{~N}$ & $17 \mathrm{~W}$ & 165 & 130 & $\mathrm{MOCN}$ \\
\hline 77 & $\mathrm{R} 029$ & 310339089393801 & NWSE 12 & $01 \mathrm{~N}$ & $17 \mathrm{~W}$ & 200 & 148 & MOCN \\
\hline 78 & $\mathrm{R} 034$ & 310412089393801 & SWSEOI & $01 \mathrm{~N}$ & $17 \mathrm{~W}$ & 230 & 147 & $\mathrm{MOCN}$ \\
\hline 79 & $\mathrm{R} 035$ & 310412089393802 & SWSEOI & $01 \mathrm{~N}$ & $17 \mathrm{~W}$ & 230 & 231 & MOCN \\
\hline \multicolumn{9}{|c|}{$\begin{array}{c}\text { [Water-level data only] } \\
\text { Lamar county }\end{array}$} \\
\hline 80 & $\mathrm{~J} 138 \quad 3$ & 310518089354101 & SWSE 34 & $02 \mathrm{~N}$ & $16 \mathrm{~W}$ & 400 & 94 & CRNL \\
\hline
\end{tabular}




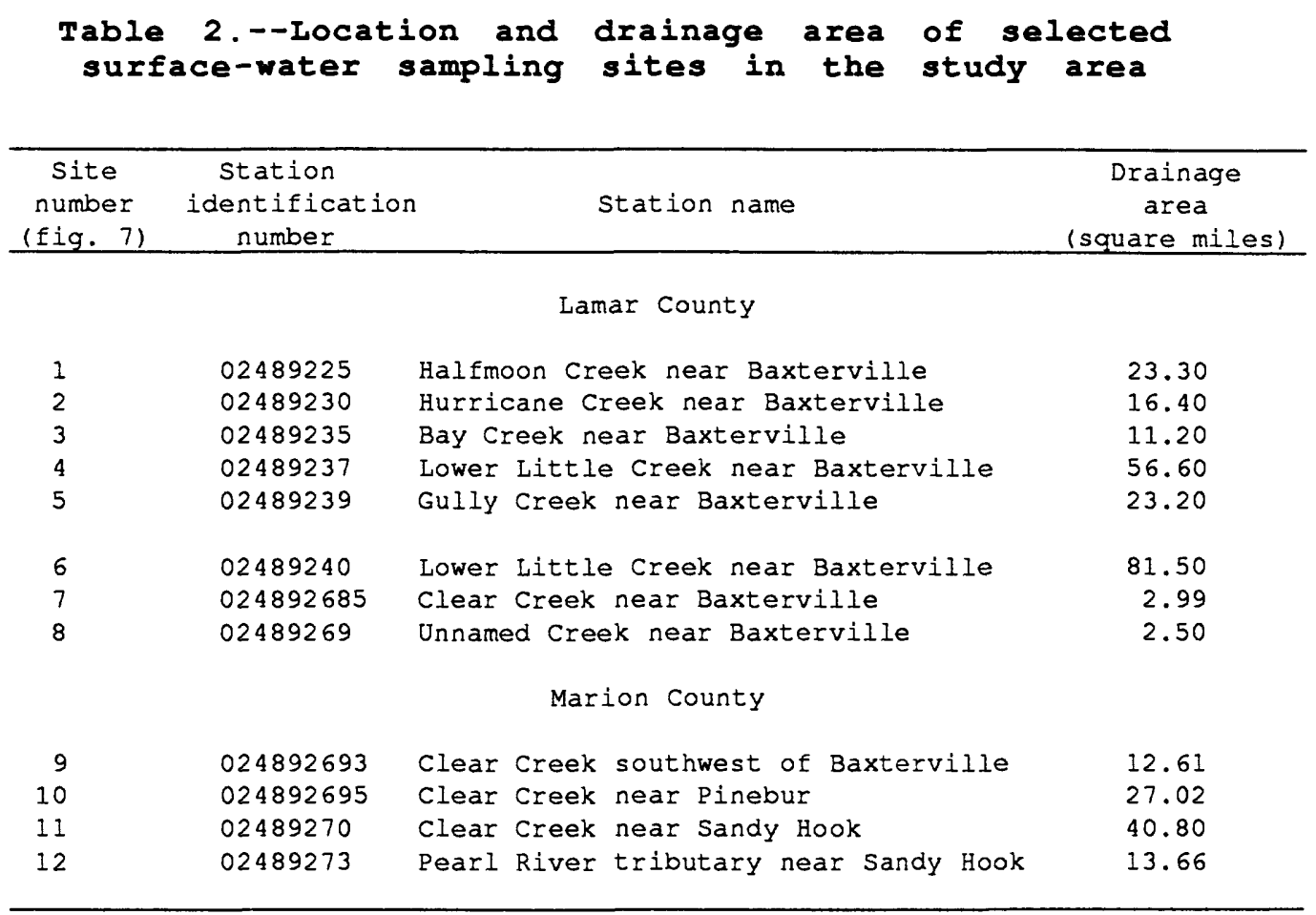

Table 3.--Summary of analyses of brine samples from the Baxterville oil field

[From Hawkins and others, 1963; Collins and others, 1966. Mean concentrations in milligrams per liter except as noted]

\begin{tabular}{lrr}
\hline Formation & Eutaw & Lower Tuscaloosa \\
\hline Depth (range, in feet) & $7,614-8,010$ & $8,734-8,901$ \\
Number of analyses & 2 & 4 \\
Dissolved solids, sum & 170,000 & 200,000 \\
Calcium & 7,800 & 18,000 \\
Magnesium & 1,200 & 2,000 \\
Sodium & 56,000 & 56,000 \\
Bicarbonate & 85 & 42 \\
Sulfate & 53 & 210 \\
Chloride & 100,000 & 120,000 \\
Bromide & 500 & 880 \\
Barium and strontium & 63 & 10 \\
Sodium to chloride ratio & & 0.54 \\
\hline
\end{tabular}


Table 4.--Selected ground-water quality data for the study area

[Dissolved constituents in milligrams per liter, except as indicated; $\mu \mathrm{S} / \mathrm{cm}$, microsiemens per centimeter at $25{ }^{\circ} \mathrm{C}$; ${ }^{\circ} \mathrm{C}$, degrees Celsius; $\mu \mathrm{g} / \mathrm{L}$, micrograms per liter; --., data not collected; <, less than.

Mean values if a well has multiple samples]

\begin{tabular}{|c|c|c|c|c|c|c|c|c|c|c|c|c|c|}
\hline $\begin{array}{l}\text { Map } \\
\text { number } \\
\text { (fig. } 5)\end{array}$ & $\begin{array}{l}\text { Spec- } \\
\text { ific } \\
\text { con- } \\
\text { duct- } \\
\text { ance } \\
(\mu \mathrm{s} / \mathrm{cm})\end{array}$ & $\mathrm{pH}$ & $\begin{array}{l}\text { Dissolved } \\
\text { solids, } \\
\text { residue } \\
\text { at } \\
180^{\circ} \mathrm{C}\end{array}$ & $\begin{array}{l}\text { Cal- } \\
\text { cium }\end{array}$ & $\begin{array}{l}\text { Mag- } \\
\text { nesi- } \\
\text { um }\end{array}$ & Sodium & $\begin{array}{c}\text { Potas- } \\
\text { sium }\end{array}$ & $\begin{array}{l}\mathrm{Bi}- \\
\text { carbon- } \\
\text { ate }\end{array}$ & $\begin{array}{l}\text { Sul- } \\
\text { fate }\end{array}$ & $\begin{array}{l}\text { Chlor- } \\
\text { ide }\end{array}$ & Bromide & $\begin{array}{c}\text { Barium } \\
(\mu \mathrm{g} / \mathrm{L})\end{array}$ & $\begin{array}{c}\text { Stron- } \\
\text { tium } \\
(\mu g / L)\end{array}$ \\
\hline
\end{tabular}

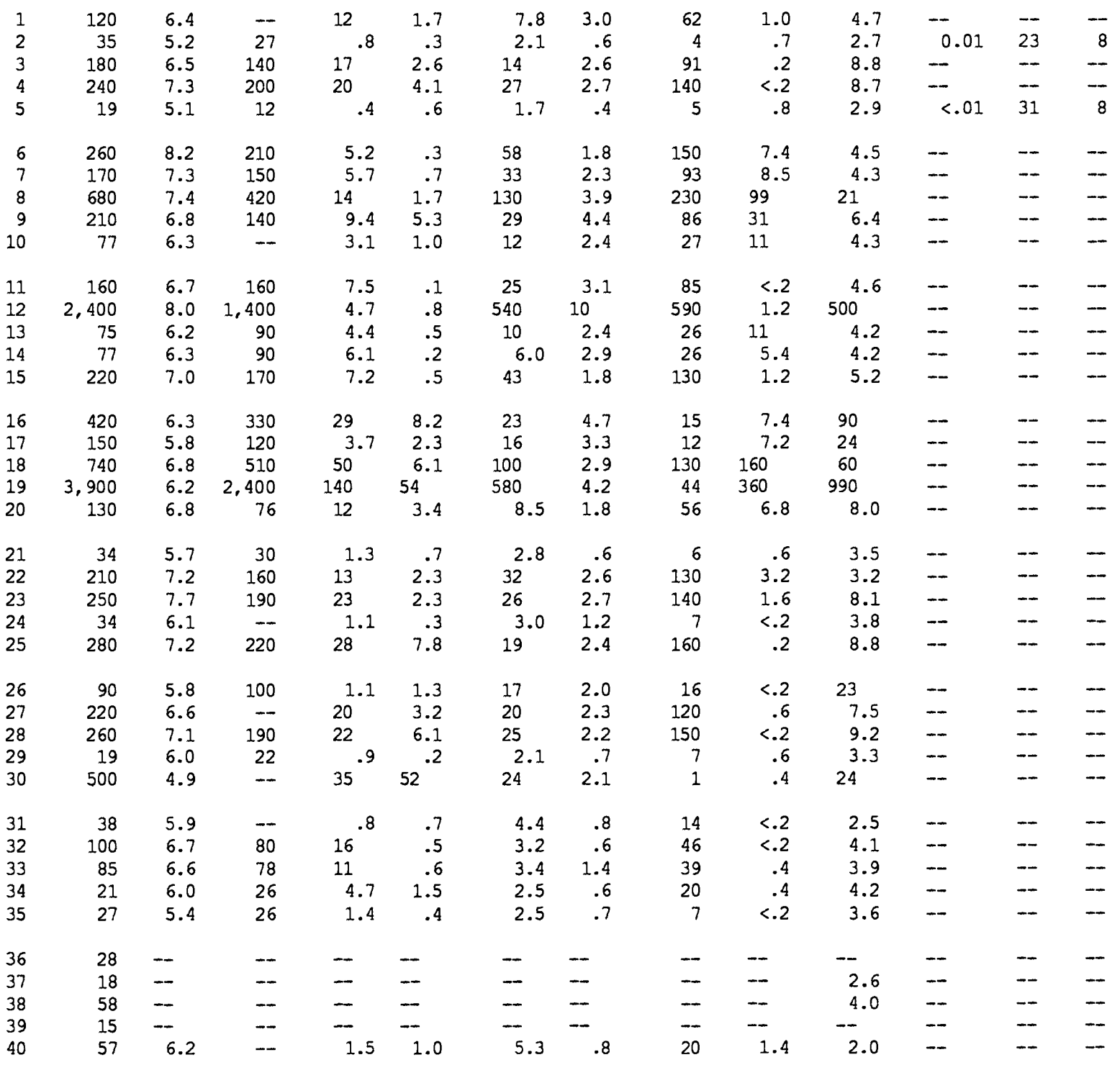


Table 4.--Selected ground-water quality data for the study area-Continued

\begin{tabular}{|c|c|c|c|c|c|c|c|c|c|c|c|c|c|}
\hline $\begin{array}{c}\text { Map } \\
\text { number } \\
\text { (fig. }\end{array}$ & $\begin{array}{l}\text { Spec- } \\
\text { ific } \\
\text { con- } \\
\text { duct- } \\
\text { ance } \\
\text { 5) }(\mu \mathrm{s} / \mathrm{cm}) \\
\end{array}$ & pH & $\begin{array}{c}\text { Dissolved } \\
\text { solids, } \\
\text { residue } \\
\text { at } \\
180^{\circ} \mathrm{C} \\
\end{array}$ & Cal- & $\begin{array}{l}\text { Mag- } \\
\text { nesi- } \\
\text { um }\end{array}$ & Sodium & $\begin{array}{l}\text { Potas- } \\
\text { sium }\end{array}$ & $\begin{array}{l}\text { Bi- } \\
\text { carbon- } \\
\text { ate }\end{array}$ & $\begin{array}{l}\text { Sul- } \\
\text { fate }\end{array}$ & $\begin{array}{l}\text { Chlor- } \\
\text { ide }\end{array}$ & Bromide & $\begin{array}{l}\text { Bariu } \\
(\mu \mathrm{g} / \mathrm{L}\end{array}$ & 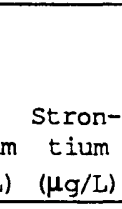 \\
\hline 41 & 230 & 7.0 & 180 & 17 & 3.8 & 28 & 2.5 & 130 & $<.2$ & 7.2 & -- & -- & -- \\
\hline 42 & 25 & 6.4 & - & .8 & .9 & 1.2 & .4 & 8 & .2 & 2.2 & -- & -- & -- \\
\hline 43 & 36 & - & -- & -- & - & - & -- & - & -- & - & -- & -- & -- \\
\hline 44 & 41 & -- & -- & -- & -- & -- & -- & - & -- & 3.0 & -- & - & -- \\
\hline 45 & 18 & -- & -- & - & -- & -- & -- & -- & -- & 4.0 & -- & -- & -- \\
\hline 46 & 24 & -- & -- & - & -- & - & -- & - & -- & -- & -- & -- & -- \\
\hline 47 & 22 & 5.4 & 26 & 1.4 & .4 & 2.5 & .7 & 7 & $<.2$ & 4.1 & -- & -- & -- \\
\hline 48 & 87 & 6.2 & 82 & 5.0 & 1.5 & 8.8 & 2.6 & 37 & 3.2 & 4.6 & .03 & 27 & 12 \\
\hline 49 & 32 & - & 48 & 2.4 & -- & - & - & $<1$ & -- & 9.9 & -- & 60 & 30 \\
\hline 50 & 46 & -- & -- & 4.0 & -- & -- & -- & 5 & -- & 9.4 & -- & $<5$ & 10 \\
\hline 51 & 118 & -- & 78 & 28 & -- & -- & -- & 11 & -- & 28 & -- & 50 & 60 \\
\hline 52 & 33 & -- & - & 2.0 & -- & -- & -- & 10 & -- & 5.1 & -- & 30 & 80 \\
\hline 53 & 74 & -- & 67 & 2.0 & - & -- & -- & 5 & -- & 18 & -- & 30 & 40 \\
\hline 54 & 32 & 5.6 & 28 & .9 & .7 & 3.0 & .7 & 6 & .4 & 3.6 & 0.01 & 48 & 12 \\
\hline 55 & 56 & 5.2 & 40 & 4.8 & 1.2 & 4.1 & .5 & 4 & .2 & 6.2 & .02 & 68 & 19 \\
\hline 56 & 21 & 6.4 & 19 & 1.0 & .1 & 1.2 & .7 & 5 & .4 & 2.0 & -- & -- & -- \\
\hline 57 & 25 & 5.5 & - & 1.4 & .1 & 1.8 & .4 & 6 & $<.2$ & 2.2 & -- & -- & -- \\
\hline 58 & 40 & 5.9 & 37 & 1.5 & .8 & 4.6 & .3 & 17 & $<.2$ & 2.5 & -- & -- & -- \\
\hline 59 & 31 & -- & -- & - & -- & -- & -- & - & -- & 2.4 & -- & -- & -- \\
\hline 60 & 34 & 6.7 & 26 & 3.3 & 1.4 & 1.5 & .4 & 18 & .8 & 2.0 & -- & -- & - \\
\hline 61 & 250 & 7.3 & 190 & 9.1 & .8 & 47 & 1.6 & 140 & 6.8 & 6.5 & -- & -- & -- \\
\hline 62 & 26 & 6.0 & 35 & 1.6 & .5 & 1.8 & .5 & 6 & .2 & 3.0 & -- & -- & -- \\
\hline 63 & 52 & 6.0 & 40 & 1.5 & 1.3 & 4.8 & 1.1 & 20 & .6 & 2.9 & -- & -- & -- \\
\hline 64 & 1,400 & 4.2 & - & 49 & 21 & 170 & -- & - & -- & 430 & 3.0 & -- & 610 \\
\hline 65 & 120 & 5.4 & 130 & 4.8 & 3.6 & 11 & 1.9 & 5 & .8 & 34 & .32 & 210 & 56 \\
\hline 66 & -. & 5.5 & 32 & 1.3 & .7 & 2.4 & 1.2 & 10 & 1.6 & 3.0 & $<.01$ & 58 & 20 \\
\hline 67 & 650 & -- & 410 & -- & -- & -- & $\ldots$ & $<5$ & -- & 163 & -- & 170 & 150 \\
\hline 68 & 50 & -- & 33 & - & -- & -- & -- & 22 & -- & 3.8 & -- & 70 & 50 \\
\hline 69 & 46 & -- & 49 & -- & -- & -- & -- & 34 & -- & 2.8 & -- & 70 & 50 \\
\hline 70 & - & -- & 120 & 4.0 & -- & - & -- & 4 & -- & 41 & -- & 210 & 70 \\
\hline \multicolumn{14}{|c|}{ Marion County } \\
\hline 71 & 130 & 6.4 & 110 & 11 & 2.6 & 9.4 & 1.8 & 60 & $<.2$ & 8.0 & -- & -- & -- \\
\hline 72 & 180 & 6.5 & 150 & 17 & 3.3 & 14 & 3.0 & 81 & 8.5 & 9.2 & -- & -- & - \\
\hline 73 & 240 & 7.7 & 150 & 1.0 & .1 & 55 & 1.1 & 140 & 6.6 & 1.7 & -- & -- & -- \\
\hline 74 & 170 & 6.5 & 140 & 17 & 3.0 & 15 & 2.4 & 89 & 2.3 & $10^{\circ}$ & $<.2$ & -- & 240 \\
\hline 75 & 110 & 6.5 & 120 & 2.0 & .5 & 18 & 1.7 & 44 & 7.6 & 2.9 & -- & -- & - \\
\hline 76 & 57 & -- & -- & -- & -- & -- & -- & - & -- & 11 & -- & -- & -- \\
\hline 77 & 54 & 5.4 & 39 & 1.8 & .9 & 2.9 & 1.6 & 13 & .3 & 2.8 & .01 & 55 & 15 \\
\hline 78 & 44 & - & 83 & 7.3 & -- & - & -- & 11 & -- & 12 & -- & $<5$ & 120 \\
\hline 79 & 3,400 & - & 2,600 & $140^{\circ}$ & - & - & -- & 7 & -- & 1,120 & -- & 4,100 & .000 \\
\hline
\end{tabular}


Table 5.--Statistical summary of water-quality data for uncontaminated ground water in the Citronelle aquifer in the study area

[Dissolved constituents in milligrams per liter, except as indictated; $\mu \mathrm{s} / \mathrm{cm}$, microsiemens per centimeter at $25{ }^{\circ} \mathrm{C}$; ${ }^{\circ} \mathrm{C}$, degrees Celsius;

$\mu \mathrm{g} / \mathrm{L}$, micrograms per liter; ROE, residue at $\left.180^{\circ} \mathrm{C}\right]$

\begin{tabular}{|c|c|c|c|c|c|c|}
\hline Parameter & $\begin{array}{c}\text { Number of } \\
\text { samples }\end{array}$ & Median & $\begin{array}{r}\text { Intero } \\
r a\end{array}$ & $\begin{array}{l}\text { quartile } \\
\text { ange }\end{array}$ & Minimum & Maximum \\
\hline Depth (feet) & 20 & 64 & 60 & -71 & 19 & 112 \\
\hline Specific conductance $(\mu \mathrm{s} / \mathrm{cm})$ & 23 & 34 & 22 & -85 & 17 & 500 \\
\hline $\mathrm{pH}$ & 23 & 5.7 & 5.4 & -6.1 & 4.9 & 6.8 \\
\hline Dissolved solids, ROE & 19 & 30 & 26 & -76 & 12 & 133 \\
\hline Calcium & 23 & 1.4 & .9 & -4.8 & .4 & 35 \\
\hline Magnesium & 23 & .6 & .3 & -1.2 & .1 & 52 \\
\hline Sodium & 23 & 3.0 & 2.2 & -4.4 & 1.2 & 24 \\
\hline Potassium & 23 & .7 & .6 & -1.3 & .3 & 3.0 \\
\hline Bicarbonate & 23 & 7.0 & 5.0 & -17 & 1.0 & 62 \\
\hline Sulfate & 23 & .4 & $<.2$ & -.6 & $<.2$ & 6.8 \\
\hline Chloride & 23 & 3.6 & 2.7 & -4.2 & 2.0 & 24 \\
\hline Bromide & 5 & $<.01$ & $<.01$ & $-<.01$ & $<.01$ & .01 \\
\hline Silica & 20 & 6.7 & 5.1 & -8.0 & 4.4 & 38 \\
\hline Barium $(\mu g / L)$ & 5 & 48 & 27 & -63 & 23 & 68 \\
\hline Iron $(\mu g / L)$ & 5 & 17 & 13 & -18 & 3 & 69 \\
\hline Strontium $(\mu \mathrm{g} / \mathrm{L})$ & 5 & 12 & 8.0 & -20 & 8.0 & 20 \\
\hline Sodium to chloride ratio & 23 & 0.79 & 0.64 & $-\quad 1.02$ & 0.35 & 1.8 \\
\hline
\end{tabular}

Table 6.--Statistical summary of water-quality data for uncontaminated ground water in the Miocene aquifer in the study area

[Dissolved constituents in milligrams per liter, except as indictated; $\mu s / \mathrm{cm}$, microsiemens per centimeter at $25{ }^{\circ} \mathrm{C} ;{ }^{\circ} \mathrm{C}$, degrees Celsius;

$\mu \mathrm{g} / \mathrm{L}$, micrograms per liter; ROE, residue at $180^{\circ} \mathrm{C}$ ]

\begin{tabular}{|c|c|c|c|c|c|c|}
\hline Parameter & $\begin{array}{c}\text { Number of } \\
\text { samples }\end{array}$ & Median & Inter & $\begin{array}{l}\text { quartile } \\
\text { ange }\end{array}$ & Minimum & Maximum \\
\hline Depth (feet) & 26 & 710 & 280 & -990 & 196 & 1,400 \\
\hline Specific conductance $(\mu \mathrm{s} / \mathrm{cm})$ & 26 & 220 & 159 & -260 & 75 & 3,900 \\
\hline $\mathrm{pH}$ & 26 & 6.8 & 6.3 & -7.3 & 5.8 & 8.2 \\
\hline Dissolved solids, ROE & 26 & 160 & 130 & -210 & 85 & 2,400 \\
\hline Calcium & 26 & 11 & 5.1 & -20 & 1.0 & 140 \\
\hline Magnesium & 26 & 2.3 & .5 & -4.4 & .1 & 54 \\
\hline Sodium & 26 & 25 & 15 & -46 & 6.0 & 580 \\
\hline Potassium & 26 & 2.6 & 2.3 & -3.2 & 1.1 & 10 \\
\hline Bicarbonate & 26 & 92 & 40 & -140 & 12 & 590 \\
\hline Sulfate & 26 & 6.9 & 1.0 & -10 & $<.2$ & 360 \\
\hline Chloride & 26 & 7.8 & 4.3 & -13 & 1.7 & 990 \\
\hline Silica & 26 & 34 & 16 & -43 & 9.2 & 63 \\
\hline Sodium to chloride ratio & 26 & 2.5 & 1.5 & -5.9 & 0.26 & 32 \\
\hline
\end{tabular}


Table 7.--Water-quality data for selected streams in the study

area

[Dissolved constituents in milligrams per liter, except as indicated; $\mathrm{ft}^{3} / \mathrm{s}$, cubic feet per second; $\mu \mathrm{s} / \mathrm{cm}$, microsiemens per centimeter at $25{ }^{\circ} \mathrm{C}$; ${ }^{\circ} \mathrm{C}$, degrees Celsius; $\mu \mathrm{g} / \mathrm{L}$, micrograms per liter;

-- , data not collected; <, less than]

\begin{tabular}{|c|c|c|c|c|c|c|c|c|c|c|c|c|c|c|c|}
\hline $\begin{array}{c}\text { Map } \\
\text { number } \\
\text { (fig. 5) }\end{array}$ & Date & $\begin{array}{c}\text { Dis- } \\
\text { charge } \\
\left(\mathrm{ft}^{3} / \mathrm{s}\right)\end{array}$ & $\begin{array}{l}\text { Spec- } \\
\text { ific } \\
\text { con- } \\
\text { duct- } \\
\text { ance } \\
(\mu \mathrm{s} / \mathrm{cm})\end{array}$ & $\mathrm{pH}$ & $\begin{array}{l}\text { Dissolved } \\
\text { solids, } \\
\text { residue } \\
\text { at } \\
180^{\circ} \mathrm{C}\end{array}$ & $\begin{array}{l}\text { d } \\
\text { Cal- } \\
\text { cium }\end{array}$ & $\begin{array}{l}\text { Mag- } \\
\text { nesi- } \\
\text { um }\end{array}$ & Sodium & $\begin{array}{c}\text { Potas- } \\
\text { sium }\end{array}$ & $\begin{array}{l}\text { Bi- } \\
\text { carbon- } \\
\text { ate }\end{array}$ & $\begin{array}{l}\text { Sul- } \\
\text { fate }\end{array}$ & $\begin{array}{l}\text { Chlor- } \\
\text { ide }\end{array}$ & Bromide & $\begin{array}{l}\text { Barium } \\
(\mu \mathrm{g} / \mathrm{L})\end{array}$ & $\begin{array}{c}\text { Stron- } \\
\text { tium } \\
(\mu g / L)\end{array}$ \\
\hline
\end{tabular}

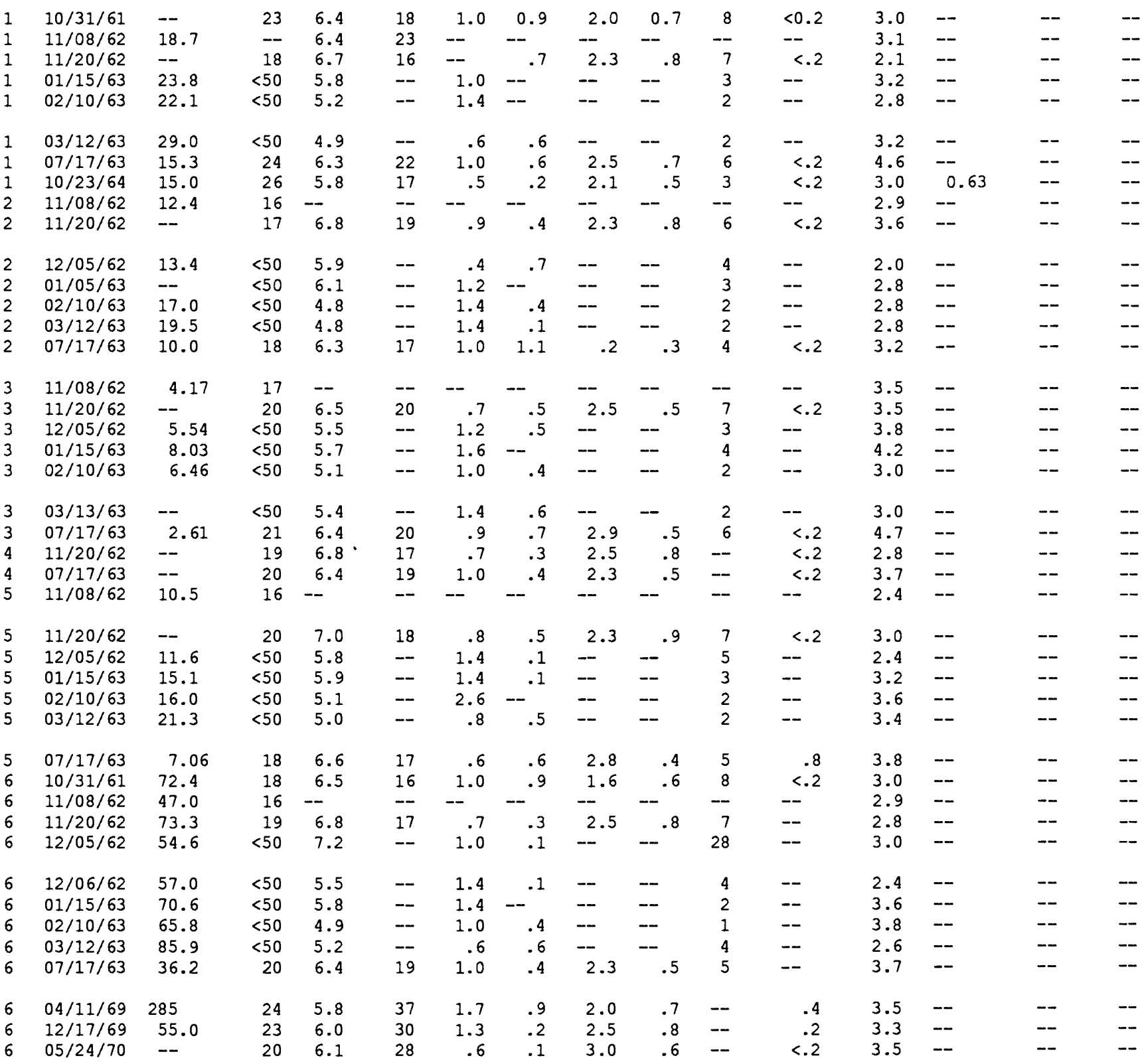


Table 7.--Surface-water quality in the study area--Continued

\begin{tabular}{|c|c|c|c|c|c|c|c|c|c|c|c|c|c|c|c|}
\hline $\begin{array}{l}\text { Map } \\
\text { number } \\
\text { (fig. 5) }\end{array}$ & Date & $\begin{array}{c}\text { Dis- } \\
\text { charge } \\
\left(\mathrm{ft}^{3} / \mathrm{s}\right)\end{array}$ & $\begin{array}{l}\text { Spec- } \\
\text { ific } \\
\text { con- } \\
\text { duct- } \\
\text { ance } \\
(\mu s / c m)\end{array}$ & $\mathrm{pH}$ & $\begin{array}{c}\text { Dissolved } \\
\text { solids, } \\
\text { residue } \\
\text { at } \\
180^{\circ} \mathrm{C}\end{array}$ & Cal- & $\begin{array}{l}\text { Mag- } \\
\text { nesi- } \\
\text { um }\end{array}$ & Sodium & $\begin{array}{l}\text { Potas- } \\
\text { sium }\end{array}$ & $\begin{array}{l}\text { Bi- } \\
\text { carbon- } \\
\text { ate }\end{array}$ & $\begin{array}{l}\text { Sul- } \\
\text { fate }\end{array}$ & $\begin{array}{l}\text { Chlor- } \\
\text { ide }\end{array}$ & Bromide & $\begin{array}{l}\text { Barium } \\
(\mu g / L)\end{array}$ & $\begin{array}{c}\text { Stron- } \\
\text { tium } \\
(\mu \mathrm{g} / \mathrm{L})\end{array}$ \\
\hline
\end{tabular}

\begin{tabular}{|c|c|c|c|c|c|c|c|c|c|c|c|c|c|c|}
\hline $08 / 18 / 82$ & -- & -- & 4.8 & -- & .7 & .4 & 1.8 & - & -- & 2.0 & 3.2 & .07 & -- & 8 \\
\hline $10 / 04 / 84$ & 1.47 & 19 & 5.6 & -- & -- & -- & 1.6 & -- & -- & - & 3.4 & -- & -- & -- \\
\hline $10 / 04 / 84$ & .54 & 810 & 5.3 & - & -- & - & 100 & -- & -- & -- & 350 & - & - & -- \\
\hline $10 / 04 / 84$ & 7.63 & 210 & 6.1 & -- & - & - & 37 & - & -- & -- & 64 & -- & -- & -- \\
\hline $08 / 18 / 82$ & 15.0 & 534 & 5.1 & -- & 23 & 3.5 & 59 & - & -- & 3.0 & 150 & 1.8 & -- & 750 \\
\hline $10 / 04 / 84$ & 9.44 & 279 & 6.0 & -- & -- & - & 36 & -- & -- & - & 83 & -- & -- & -- \\
\hline $10 / 03 / 84$ & 14.5 & 135 & 6.5 & 112 & 7.2 & 1.6 & 21 & 1.1 & 7.0 & .8 & 48 & .31 & 110 & 210 \\
\hline $03 / 21 / 85$ & 601 & 66 & 5.9 & 46 & 3.1 & .8 & 7.3 & .9 & 5.0 & 3.2 & 15 & .10 & 65 & 67 \\
\hline $05 / 13 / 85$ & 21.1 & 190 & 6.2 & -- & -- & -- & 25 & - & -- & -- & 51 & -- & -- & -- \\
\hline $07 / 25 / 85$ & 49.5 & 375 & 5.5 & - & - & -- & 42 & - & -- & -- & 100 & -- & -- & - \\
\hline $08 / 06 / 85$ & 13.2 & 168 & 6.5 & -- & -- & - & 20 & - & -- & -- & 46 & - & -- & - \\
\hline $08 / 27 / 85$ & 17.7 & 280 & 6.2 & 192 & -- & -- & 37 & -- & -- & -- & 76 & -- & -- & -- \\
\hline
\end{tabular}

Pearl River tributary

\begin{tabular}{llllllllllllllll}
12 & $10 / 03 / 84$ & 4.78 & 36 & 6.2 & 40 & 2.4 & .9 & 2.8 & 1.3 & 15 & 1.5 & 3.8 & .01 & 48 & 20 \\
12 & $03 / 21 / 85$ & 104 & 32 & 6.1 & 29 & 1.9 & .7 & 2.4 & .8 & 6.0 & 4.3 & 4.2 & .03 & 43 & 16 \\
12 & $03 / 22 / 85$ & 41.1 & 32 & 6.2 & -- & -- & -- & 2.2 & -- & -- & -- & 3.4 & -- & -- & -- \\
12 & $04 / 24 / 85$ & 20.8 & 40 & 6.3 & 21 & -- & -- & 2.6 & -- & -- & -- & 3.0 & -- & -- & -- \\
12 & $08 / 07 / 85$ & 5.79 & 42 & 6.4 & -- & -- & -- & 2.8 & -- & -- & -- & 3.1 & -- & -- & -- \\
\hline
\end{tabular}


Table 8.--Water-quality data for Clear Creek and the Pearl River tributary during low-flow and high-flow periods

[Dissolved constituents in milligrams per liter, except as indicated; $\mathrm{ft}^{3} / \mathrm{s}$, cubic feet per second; $\mu \mathrm{s} / \mathrm{cm}$, microsiemens per centimeter at $25{ }^{\circ} \mathrm{C}$; ${ }^{\circ} \mathrm{C}$, degrees Celsius; $\mu \mathrm{g} / \mathrm{L}$, micrograms per liter; ROE, residue at $180{ }^{\circ} \mathrm{C}$ ]

\begin{tabular}{|c|c|c|c|c|}
\hline \multirow[b]{2}{*}{ Constituent } & \multicolumn{2}{|c|}{$\begin{array}{l}\text { Clear Creek } \\
\text { Site } 11\end{array}$} & \multicolumn{2}{|c|}{$\begin{array}{c}\text { Pearl River tributary } \\
\text { site } 12 \\
\end{array}$} \\
\hline & Low flow & High flow & Low flow & High flow \\
\hline Date & $10 / 03 / 84$ & $03 / 21 / 85$ & $10 / 03 / 84$ & $03 / 21 / 85$ \\
\hline Discharge $\left(\mathrm{ft}^{3} / \mathrm{s}\right)$ & 14.5 & 569 & 4.78 & 104 \\
\hline Specific conductance $(\mu \mathrm{s} / \mathrm{cm})$ & 135 & 66 & 36 & 32 \\
\hline $\mathrm{pH}$ & 6.5 & 5.9 & 6.2 & 6.1 \\
\hline Dissolved solids, ROE & 110 & 46 & 40 & 29 \\
\hline Calcium & 7.2 & 3.1 & 2.4 & 1.9 \\
\hline Magnesium & 1.6 & .8 & .9 & .7 \\
\hline Sodium & 21 & 7.3 & 2.8 & 2.4 \\
\hline Potassium & 1.1 & .9 & 1.3 & .8 \\
\hline Bicarbonate & 7.0 & 5.0 & 15 & 6.0 \\
\hline Sulfate & .8 & 3.2 & 1.5 & 4.3 \\
\hline Chloride & 48 & 12 & 3.8 & 4.2 \\
\hline Bromide & .31 & .10 & .01 & .03 \\
\hline Barium $(\mu \mathrm{g} / \mathrm{L})$ & 110 & 65 & 48 & 43 \\
\hline Strontium $(\mu \mathrm{g} / \mathrm{L})$ & 210 & 67 & 20 & 16 \\
\hline Sodium to chloride ratio & .44 & .49 & .74 & .57 \\
\hline
\end{tabular}

